\title{
Digestive enzymes of two brachyuran and two anomuran land crabs from Christmas Island, Indian Ocean
}

\author{
Stuart M. Linton · Reinhard Saborowski • \\ Alicia J. Shirley $\cdot$ Jake A. Penny
}

Received: 16 December 2013 / Revised: 28 January 2014 / Accepted: 6 February 2014

(C) Springer-Verlag Berlin Heidelberg 2014

\begin{abstract}
The digestive ability of four sympatric land crabs species (the gecarcinids, Gecarcoidea natalis and Discoplax celeste and the anomurans, Birgus latro and Coenobita perlatus) was examined by determining the activity of their digestive enzymes. The gecarcinids are detritivores that consume mainly leaf litter; the robber crab, B. latro, is an omnivore that preferentially consumes items high in lipid, carbohydrate and/or protein; C. perlatus is also an omnivore/detritivore. All species possess protease, lipase and amylase activity for hydrolysing ubiquitous protein, lipid and storage polysaccharides (glycogen and starch). Similarly all species possess enzymes such as $N$-acetyl- $\beta$-Dglucosaminidase, the cellulases, endo- $\beta-1,4$-glucanase and $\beta$-glucohydrolase and hemicellulases, lichenase and laminarinase for the respective hydrolysis of structural substrates chitin, cellulose and hemicelluloses, lichenan and laminarin. Except for the enzyme activities of $C$. perlatus, enzyme activity could not be correlated to dietary preference. Perhaps others factors such as olfactory and locomotor ability and metabolic status may determine the observed dietary preferences. The digestive fluid of $C$. perlatus possessed
\end{abstract}

Communicated by I.D. Hume.

S. M. Linton · A. J. Shirley · J. A. Penny

School of Life and Environmental Sciences, Deakin University,

Pigdons Road, Waurn Ponds, VIC 3217, Australia

S. M. Linton $(\bowtie)$

School of Life and Environmental Sciences, Deakin University, Locked bag 20000, Geelong, VIC 3220, Australia

e-mail: stuart.linton@deakin.edu.au

R. Saborowski

Functional Ecology, Alfred Wegener Institute for Polar and Marine Research, P.O. Box 120161, 27570 Bremerhaven, Germany higher endo- $\beta$-1,4-glucanase, lichenase and laminarinase activities compared to that of the other species. Thus, $C$. perlatus may be efficient at digestion of cellulose and hemicellulose within plant material. Zymography indicated that the majority of protease, lipase, phosphatase, amylase, endo- $\beta$-1,4-glucanase, $\beta$-glucohydrolase and $N$-acetyl- $\beta$ D-glucosaminidase isozymes were common to all species, and hence were inherited from a common aquatic ancestor. Differences were observed for the phosphatase, lipase and endo- $\beta-1,4$-glucanase isozymes. These differences are discussed in relation to phylogeny and possible evolution to cope with the adoption of a terrestrial diet.

Keywords Land crabs · Digestion - Digestive enzymes · Zymography

\section{Introduction}

The gecarcinid land crabs, Gecarcoidea natalis (Pocock 1888) and Discoplax celeste (Ng and Davie 2012) and the coenobitid land crabs, Birgus latro (Linnaeus 1767) and Coenobita perlatus (Milne Edwards 1853) are sympatric species on Christmas Island, Indian Ocean. All these species consume a variety of material ranging from plant material in the form of fruits, seeds and in some cases leaf litter to animal material in the form of carrion, dead conspecifics and in some cases prey. The detailed composition of digestive enzymes in these species in terms of their activities, number of isoforms and molecular masses is unknown. However, given the ubiquitous nature of essential nutrients they are likely to possess proteases for hydrolysis of protein, lipases for the hydrolysis of lipid and carbohydrases such as $\alpha$-amylase for the hydrolysis of storage carbohydrate. 
Although these four species are omnivorous/detritivorous, they have different foraging strategies and display a distinct preference for certain dietary items. The red crab, Gecarcoidea natalis and the blue crab Discoplax celeste have small home ranges in the non-breeding season and their foraging is restricted to these areas (Table 1). The diet of both species consists mainly of brown leaf litter (low in nitrogen and high in cellulose and hemicellulose content) with small amounts of fruits, seeds and animal material, when available (Table 1). The anomuran land crabs, B. latro and the terrestrial hermit crabs, Coenobita sp belong to the family, Coenobitidae (Davie 2002). B. latro is an omnivore with a distinct preference for items such as fruits, seeds and animal material which are high in carbohydrate, lipid and protein (Linton and Greenaway 2007; Wilde et al. 2004) (Table 1). They are capable of travelling large distances, up to $1 \mathrm{~km}$ per day, and possess an excellent olfactory ability which allow them to seek out their preferred food (Stensmyr et al. 2005; Greenaway 2001; Fletcher et al. 1990). Terrestrial hermit crabs such as $C$. perlatus are nocturnal and are restricted to areas near the shore such as beaches and terrace forest (Hartnoll 1988). Coenobita species are largely omnivores/detritivores, which consume a variety of plant, animal and shoreline detritus (Table 1) (Grubb 1971; Barnes 1997; Greenaway 2003). The diet for C. perlatus on Christmas Island species is largely unknown, but given the species is found near the shore and not in the terrace forest it may consume, like other Coenobita, strandline detritus, some plants and perhaps algae scrapped off the rocks at night.

Given these differences in feeding preferences between the species, the question arises whether these preferences are reflected in the complement (activity and presence) of digestive enzymes? In particular are the activities of the digestive enzymes higher for a preferred substrate? Digestive enzymes are likely to be correlated to the dietary compounds present in the diet with the animal being economical, producing only enzymes it would require and not wasting energy-producing ones it would not use (Karasov et al. 2011). Activities of digestive enzymes have been correlated to dietary preferences in other species of decapod crustaceans, amphipods and vertebrates such as fish and bats (family Phyllostomidae) (Johnston and Freeman 2005; Karasov et al. 2011; Johnston and Yellowlees 1998; Johnston et al. 2004; German et al. 2010; Schondube et al. 2001). Generally, carnivorous species possess high protease activities, species which consume starchy items and algae possess high amylase and laminarinase activities, insectivorous species possess high chitinase and trehalase activities, while species which consume plant material have high cellulase activities (Johnston and Freeman 2005; Karasov et al. 2011; Johnston and Yellowlees 1998; Johnston et al. 2004; German et al. 2010; Schondube et al. 2001). A diverse range of digestive enzymes is likely in G. natalis, D. celeste and $B$. latro given the diverse diet and previous demonstrations that these species are capable of digesting a range of substrates (Greenaway and Linton 1995; Greenaway and Raghaven 1998; Wilde et al. 2004). However given the differences in feeding ecology, the activities of particular classes of enzymes, may be higher to reflect the species preferred dietary substrates. The gecarcinids may possess high cellulase and hemicellulase activities while $B$. latro may possess high protease, lipase and amylase activities.

Activities of digestive enzymes were measured within the digestive fluid of the gecarcinids, G. natalis and $D$. celeste and the anomurans, $B$. latro and $C$. perlatus to determine one, the presence of the different types of digestive enzymes and two, if the dietary preferences of the species were reflected in the enzyme complement. Zymograms were also conducted to determine the number and estimated size of the digestive enzymes. Similarities in activity, number and size of enzymes across all species may suggest that the enzymes were inherited from a common aquatic ancestor. Any difference between the gecarcinid and coenobitid groups may be indicative of phylogeny, while differences between closely related species, G. natalis and D. celeste or $B$. latro and $C$. perlatus may be indicative of adaptations to a terrestrial diet.

\section{Methods}

Sampling of digestive fluid

Land crabs Birgus latro (Linnaeus, 1767), Coenobita perlatus (H. Milne Edwards 1837), Gecarcoidea natalis (Pocock, 1888) and Discoplax celeste (Ng and Davie 2012) were collected from the rainforest on Christmas Island, Indian Ocean and held at the Christmas Island Research station for $24 \mathrm{~h}$ without food. Only male G. natalis and $D$. hirtipes were collected. The mass range of G. natalis and D. hirtipes was, respectively, 103-225 and 251-424 g. Mixed sex $B$. latro and $C$. perlatus were collected. The mass of $B$. latro ranged from 1 to $2 \mathrm{~kg}$, while the mass of $C$. perlatus ranged from 16 to $60 \mathrm{~g}$. Digestive fluid was then collected from the cardiac stomach of each crab. To do this, one experimenter held the crab, ventral side up while another experimenter inserted the narrow tip of a $10-\mathrm{mL}$ Eppendorf Combitip into the cardiac stomach and applied gentle suction to collect the fluid. Depending on the size of the crab, between 2 and $4 \mathrm{~mL}$ of digestive fluid was collected. Digestive fluid samples were immediately dispensed into 2-mL screw top tubes, and frozen in a liquid nitrogen-cooled biological shipper (CX100 Taylor-Wharton). Samples were then air-freighted back to the laboratories at Deakin University, Geelong, Australia and the Alfred Wegener Institute in Bremerhaven, Germany. 


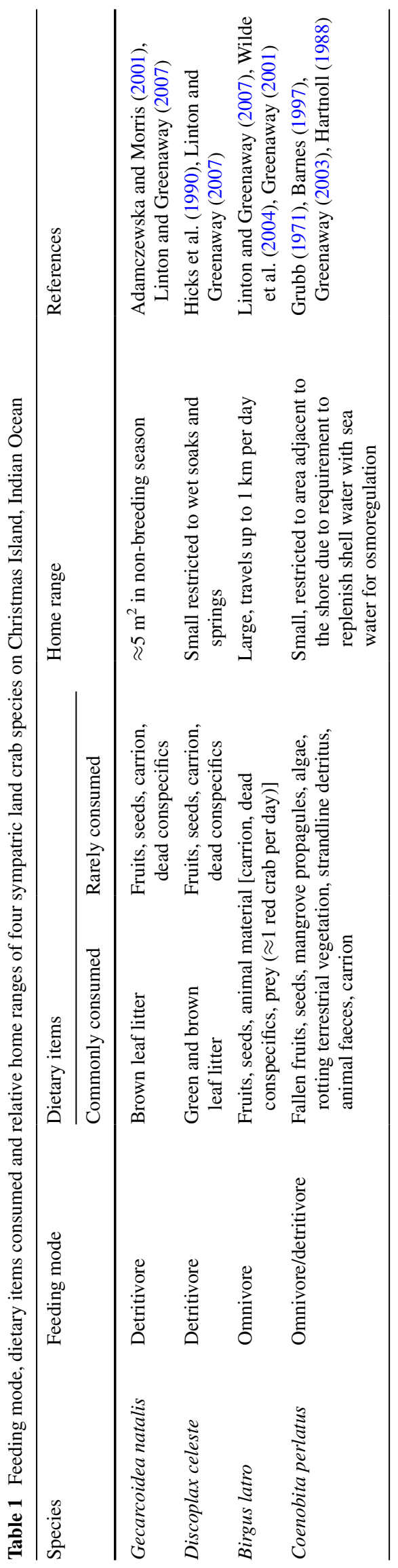

Preparation of digestive fluid for enzyme assays

The digestive fluid samples were centrifuged at $10,000 \mathrm{~g}$ for 10 min to pellet any particulate matter and then diluted with demineralised water. The samples were assayed for total protein and activities of the following enzymes, total protease, serine protease, cysteine protease, trypsin, chymotrypsin, alanine amino peptidase, lipase, esterase, alkaline phosphatase, $N$-acetyl- $\beta$-D-glucosaminidase (NAGase), laminarinase, endo- $\beta$-1,4-glucanase, lichenase, amylase and $\beta$-1,4-glucosidase (Table 2). Except for total protease activities, which were expressed as the change in absorbance per minute per mg protein, enzyme activities were expressed as units (U) ( $\mu$ mol of product produced or consumed) per minute per mg of protein. All enzyme assays were conducted at $30{ }^{\circ} \mathrm{C}$. Zymograms were also conducted to estimate the size and number of the major digestive enzymes: total protease, esterase, $N$-acetyl- $\beta$-Dglucosaminidase (NAGase), phosphatase, $\beta$-glucosidase and endo- $\beta$-1,4-glucanase (Table 3).

\section{Total protein measurement}

Protein in the digestive fluid was measured using a commercial Bradford reagent (Biorad, Hercules, CA \#5000006) as per the manufacturers protocol (Bradford 1976). Solutions of bovine serum albumin at concentrations between 0 and $1 \mathrm{mg} \mathrm{mL}{ }^{-1}$ were used as standards. Digestive fluid samples were diluted so that their absorbance in the protein assays was within the range of the standards.

Enzymes assays

\section{Protease enzymes}

Using the methods of Teschke and Saborowski (2005) and Saborowski et al. (2004) total protease, trypsin, chymotrypsin and alanine amino peptidase activities were measured in the digestive fluid (Table 2). Inhibition assays were also conducted on the digestive fluid using the methods of Teschke and Saborowski (2005) to determine the percentage of serine, cysteine and other proteases, possibly metalloproteases within it (Table 2).

\section{Lipase, esterase and $N$-acetyl- $\beta$-D-glucosaminidase}

Lipase, esterase and $N$-acetyl- $\beta$-D-glucosaminidase activities were measured in digestive fluid using the respective substrates 4-methylumbelliferyl oleate (75164, Fluka), 4-methylumbelliferyl butyrate (19362, Sigma) and 4-methylumbelliferyl $N$-acetyl- $\beta$-D-glucosaminide (M2133 Sigma) as per the method of Knotz et al. (2006) (Table 2). These assays measure the continuous release of 


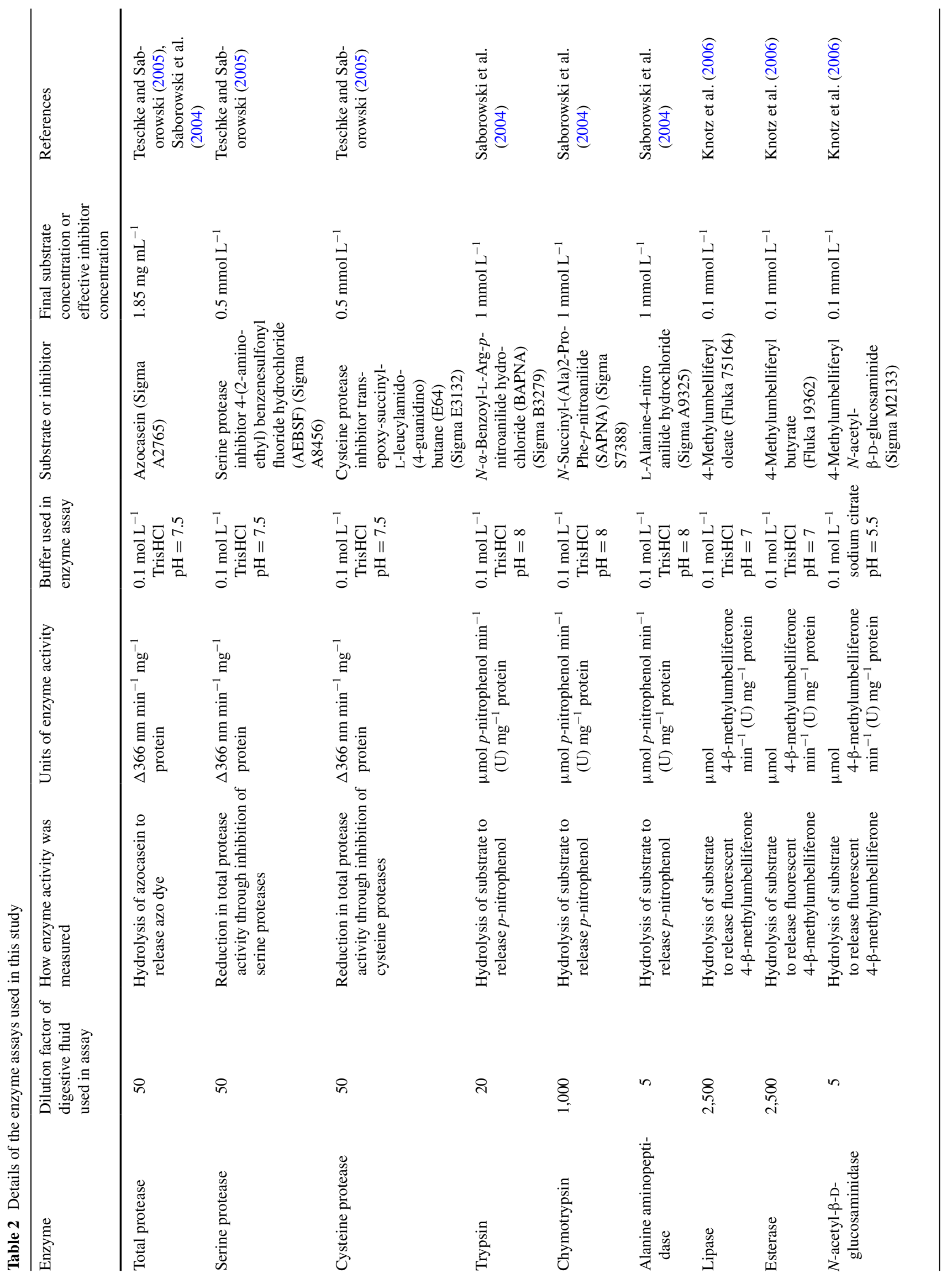




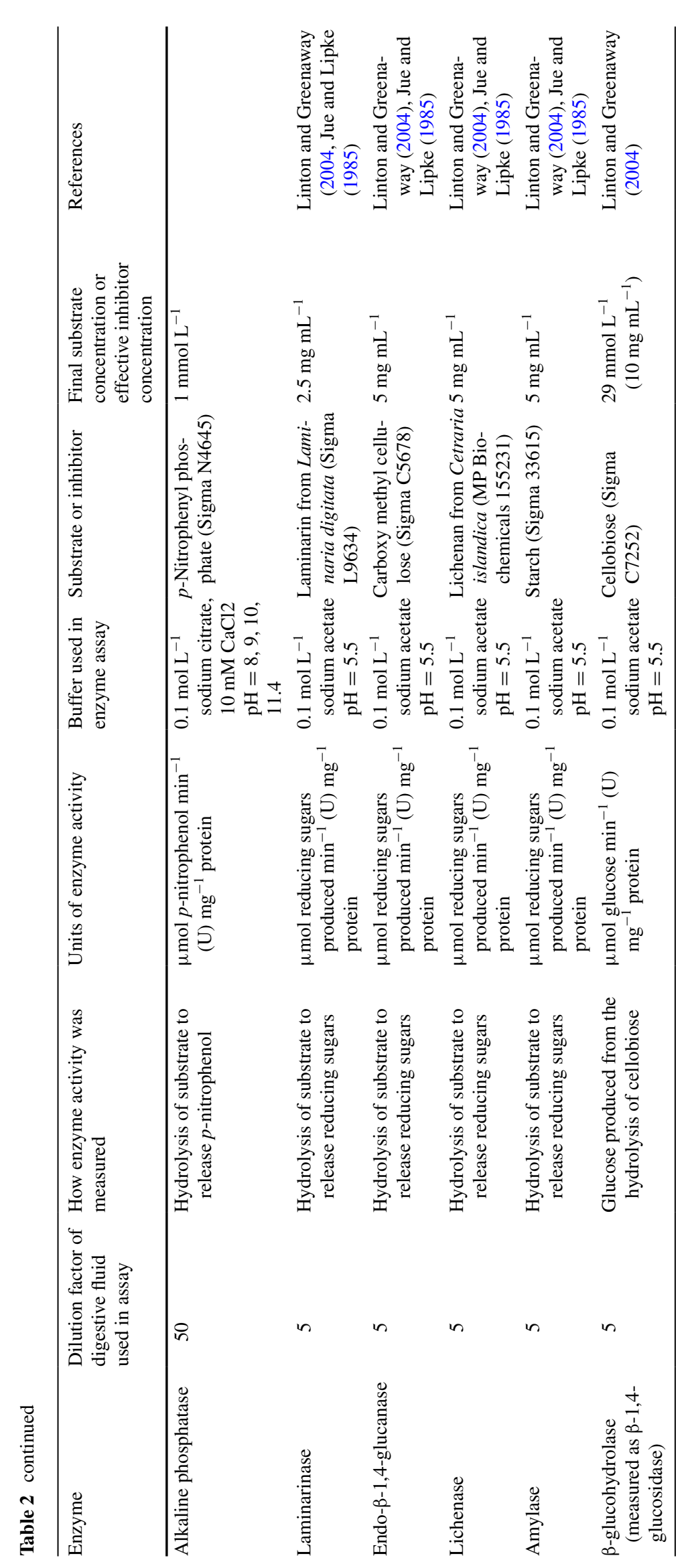


Table 3 Substrates, their concentration and the buffers used in the activity staining of the polyacrylamide gels for the enzyme activities listed

\begin{tabular}{|c|c|c|c|c|}
\hline Enzyme & Substrate & Substrate concentration & Buffer & Reference for the methods \\
\hline$N$-Acetyl- $\beta$-D-glucosidase & $\begin{array}{l}\text { 4-Methylumbelliferyl } \\
\quad N \text {-acetyl- } \beta \text {-D-glucosaminide } \\
\text { (Sigma M2133) }\end{array}$ & $100 \mu \mathrm{mol} \mathrm{L}^{-1}$ & $\begin{array}{l}0.1 \text { mol L }^{-1} \text { sodium acetate } \\
\text { pH } 5.5\end{array}$ & Prim et al. (2003) \\
\hline Alkaline phosphatase & $\begin{array}{l}\text { 4-Methylumbelliferyl phos- } \\
\text { phate (Sigma M8883) }\end{array}$ & $100 \mu \mathrm{mol} \mathrm{L}^{-1}$ & $\begin{array}{l}0.1 \mathrm{~mol} \mathrm{~L}^{-1} \text { TrisHCl, } \mathrm{pH} 8 \text { for } \\
\text { the gecarcinid species, pH } 9 \\
\text { for the coenobitid species }\end{array}$ & Prim et al. (2003) \\
\hline Esterase & $\begin{array}{l}\text { 4-Methylumbelliferyl butyrate } \\
\text { (Fluka 19362) }\end{array}$ & $100 \mu \mathrm{mol} \mathrm{L}^{-1}$ & $0.1 \mathrm{~mol} \mathrm{~L}^{-1}$ TrisHCl $\mathrm{pH} 7$ & Prim et al. (2003) \\
\hline $\begin{array}{l}\beta \text {-1,4-glucosidase } \\
\quad(\beta \text {-glucohydrolase })\end{array}$ & $\begin{array}{l}\text { 4-Methylumbelliferyl- } \beta \text {-D- } \\
\text { glucopyranoside (Sigma } \\
\text { M3633) }\end{array}$ & $100 \mu \mathrm{mol} \mathrm{L}^{-1}$ & $\begin{array}{l}0.1 \mathrm{~mol} \mathrm{~L}^{-1} \text { sodium acetate } \\
\mathrm{pH} 5.5\end{array}$ & Prim et al. (2003) \\
\hline Total proteinase & Haemoglobin (Sigma H2625) & $2.5 \mathrm{mg} \mathrm{mL}^{-1}$ & $0.1 \mathrm{~mol} \mathrm{~L}^{-1}$ TrisHCl, $\mathrm{pH} 7$ & del Toro et al. (2006) \\
\hline
\end{tabular}

the fluorescent molecule 4- $\beta$-methylumbelliferone (MUF) from the hydrolysis of the substrates.

\section{Alkaline phosphatase}

Alkaline phosphatase assays were conducted on digestive fluid, which was diluted 50 times at various alkaline $\mathrm{pH}$ values of $8,9,10$ and 11.4. This assay used $p$-nitrophenyl phosphate as the substrate and measured the release of $p$-nitrophenol when it was hydrolysed. For these assays, $10 \mu \mathrm{L}$ of 50 times diluted digestive fluid, $250 \mu \mathrm{L}$ of $25 \mathrm{mmol} \mathrm{\textrm {L } ^ { - 1 }}$ Tris buffer adjusted to either $\mathrm{pH} \mathrm{8,} \mathrm{9,} 10$ and 11.4 and $20 \mu \mathrm{L}$ of $15 \mathrm{mmol} \mathrm{L}{ }^{-1} p$-nitrophenol phosphate (final substrate concentration $=1 \mathrm{mmol} \mathrm{L}^{-1}$ ) was added to a 96-well plate and incubated at room temperature for $1 \mathrm{~h}$. After this incubation, the reaction was stopped and the colour of $p$-nitrophenol was developed by the addition of $20 \mu \mathrm{L}$ of $2 \mathrm{~mol} \mathrm{~L}^{-1}$ sodium hydroxide. Absorbance of the samples within the 96-well plates was measured at $405 \mathrm{~nm}$ using a Dynatech MR7000 microplate reader. Absorbances for the $p$-nitrophenol were converted into $\mu \mathrm{mol}$ using the absorbance of $p$-nitrophenol standards ranging in concentration from $2 \mu \mathrm{M}$ to $1.25 \mathrm{mM}$.

\section{Carbohydrases: laminarinase, endo- $\beta$-1,4-glucanase, lichenase, $\beta$-1,4-glucosidase and amylase}

Activities of the carbohydrase enzymes, laminarinase, endo$\beta$-1,4-glucanase, lichenase and amylase were measured by the rate of production of reducing sugars from the hydrolysis of their respective substrates laminarin, carboxy methyl cellulose, lichenan and starch (Table 2). $\beta$-1,4-glucosidase ( $\beta$-glucohydrolase) activities were measured by the production of glucose from the hydrolysis of cellobiose. The methods for all of these assays were as per Linton and
Greenaway (2004) and Figueiredo et al. (2001). Reducing sugars were measured as per the method of Jue and Lipke (1985).

\section{Enzyme activity staining of SDS-PAGE gels}

Proteins and enzymes within the digestive fluid samples were separated with SDS polyacrylamide gel electrophoresis using an $8 \times 10 \mathrm{~cm}, 12 \%$ polyacrylamide gel run at $15 \mathrm{~mA}$ per gel, as per the method of Laemmli (1970). Digestive fluid samples $(15 \mu \mathrm{L})$ were mixed with the same amount of SDS-PAGE buffer $(0.021 \%$ bromophenol blue, $31 \%$ glycerol, $4.2 \%$ sodium dodecyl sulphate and $0.13 \mathrm{~mol} \mathrm{~L}^{-1}$ TrisHCl buffer $\mathrm{pH}=6.8$ ). To preserve the potential functionality of the proteins, the samples were neither heated nor treated with $\beta$-mercaptoethanol. After electrophoresis, the polyacrylamide gels were then stained for either $N$-acetyl- $\beta$-D-glucosaminidase, alkaline phosphatase, esterase and $\beta$-glucosidase activity using the methods modified from those of Prim et al. (2003) and Allardyce et al. (2010) (Table 3). Different substrates and buffers were used for different enzymes (Table 3). In these gels, the enzymes hydrolyse the substrate to release the fluorescent molecule, 4- $\beta$-methylumbelliferone that produces a thin fluorescent band upon UV illumination. After activity staining, the gels were counterstained with Coomassie Brilliant blue R $(0.05 \%$ brilliant blue $\mathrm{R}$ dissolved in $50 \%$ water, $10 \%$ acetic acid, $40 \%$ methanol) to visualise the protein standards. Photographs of the same fluorescent and Coomassie blue stained gel were scaled to the same size within Corel PhotoPaint X3 and the size of the protein bands estimated by comparing their migration distance to that of the protein standards [Either Invitrogen Mark 12 unstained standards (\#LC5677), Carl Roth Roti-Mark standards (\#T851) or Sigma low range molecular weight standards (\#M3913)]. The method for 
staining of total protease activities were as per del Toro et al. (2006) and García-Carreño et al. (1993).

Statistical analysis

Mean enzyme activities among species were analysed statistically using a one-way ANOVA followed by StudentNewman-Keuls post hoc tests. If the data were not normally distributed or did not possess equal variance among the groups, then a Kruskal-Wallis non-parametric ANOVA followed by either Student-Newman-Keuls (equal group size) or Dunn's (unequal group size) post hoc tests was conducted. Sigma Plot 11 was used to calculate statistical probabilities. Means were deemed to be significantly different if the calculated probabilities were $<0.05$.

\section{Results}

Specific activities of the major digestive enzymes

\section{Proteases}

The digestive fluid of G. natalis had a significantly higher total protease activity than that within the digestive fluids from D. celeste, B. latro and C. perlatus (Fig. 1). The total protease activity of the digestive fluid from the latter three species was similar and ranged between 0.84 and 1.04 $\Delta E_{366} \mathrm{~min}^{-1} \mathrm{mg}^{-1}$ protein.

Of the total protease activity in all species, and like that of other decapods, serine proteases such as trypsin and chymotrypsin made up the majority of the activity, while cysteine and other proteases most likely metalloprotease such as alanine aminopeptidase were minor constituents of the total activity (Fig. 2; Terra and Ferreira 2005; Vonk and Western 1984; Díaz-Tenorio et al. 2006; Johnston et al. 1995; Sainz et al. 2004; Gimenez et al. 2002). In G. natalis and B. latro, cysteine and other proteases constituted similar percentages (7-17\%) of total protease activity, while in D. celeste and C. perlatus the proportion of other proteases was higher (31$35 \%$ ) than that of the cysteine proteases (0-1.3\%) (Fig. 2).

Out of all of the protease enzymes measured, chymotrypsin had the highest specific activity and thus accounts for the majority of the serine protease activity. The digestive fluid from $D$. celeste had the highest chymotrypsin-specific activities (24.6 $\mathrm{U} \mathrm{mg}^{-1}$ protein), followed by $G$. natalis and then $B$. latro and $C$. perlatus, which had similar chymotrypsinspecific activities of $0.8-5.3 \mathrm{U} \mathrm{mg}^{-1}$ protein (Fig. 3a). The trypsin-specific activity of the digestive fluid from $B$. latro was higher $\left(0.19 \mathrm{U} \mathrm{mg}^{-1}\right.$ protein) than those of the other species examined (Fig. 3b). The digestive fluid of all the other species, G. natalis, D. celeste and C. perlatus had similar trypsin-specific activities of $0.041-0.094 \mathrm{U} \mathrm{mg}^{-1}$ protein

\section{Total protease activity}

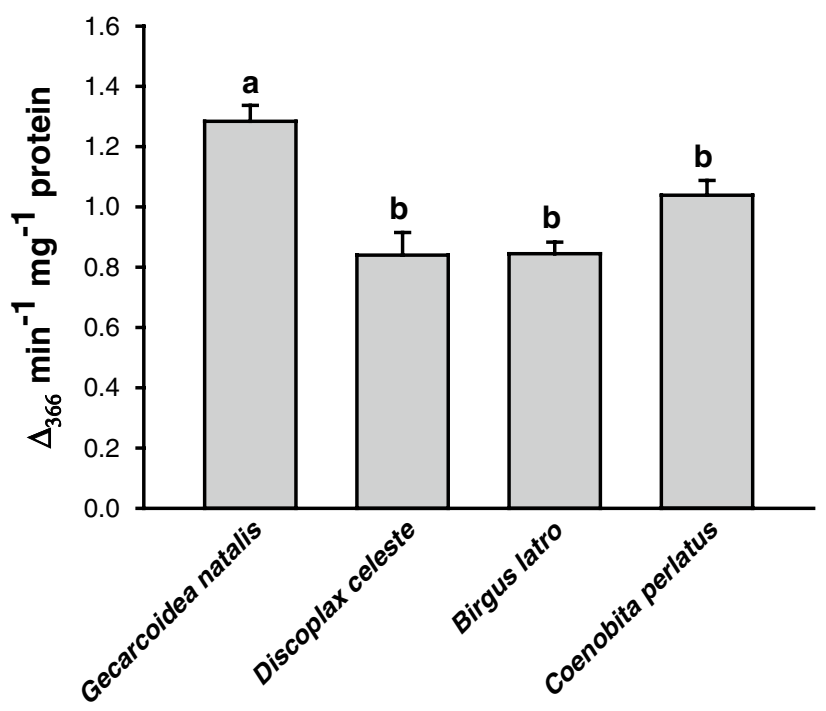

Fig. 1 Total protease-specific activity [change in absorbance at $366 \mathrm{~nm}\left(\Delta_{366}\right) \mathrm{min}^{-1} \mathrm{mg}^{-1}$ protein] within the digestive fluid of $G$. natalis, D. celeste, B. latro and $C$. perlatus. Total protease activity was measured by the release of azo dye from the hydrolysis of azocasein. Data are expressed as mean $\pm \operatorname{SEM}(n=5)$. Different letters above the bars indicate significantly different means $(P<0.05$, Kruskal-Wallis ANOVA followed by Student-Newman-Keuls post hoc tests on ranks)

(Fig. 3b). The digestive fluid from all species examined had alanine amino peptidase activities, ranging from 0.003 to $0.012 \mathrm{U} \mathrm{mg}^{-1}$ protein. Due to high variability, these values were not different between species (Fig. 3c).

Lipase and other esterase enzymes

Lipases and other esterases are enzymes which are capable of hydrolysing ester bonds. Lipase activity was measured with two substrates, a short $\mathrm{C}_{4}$ substrate, MUF butyrate and a long $\mathrm{C}_{18}$ substrate, MUF oleate. The $\mathrm{C}_{18}$ substrate is hydrolysed by true lipases that cleave the ester bonds within the triacylglycerols at the hydrophilic-hydrophobic boundary (Park et al. 2008; Prim et al. 2003). The short butyrate substrate can be hydrolysed by lipases, other esterases and possibly serine proteases such as trypsin and chymotrypsin since they all share a common catalytic triad (Rivera-Perez et al. 2011). Lipase activities, measured with the $\mathrm{C}_{18}$ substrate, within the digestive fluid of G. natalis, $D$. celeste and B. latro were 2-3 times higher than the corresponding activities measured with the $\mathrm{C}_{4}$ substrate (Fig. 4a, b). In contrast, for $C$. perlatus, the lipase activities measured with the $\mathrm{C}_{4}$ substrate were higher than those measured with the $\mathrm{C}_{18}$ substrate (Fig. 4). The lipase activities measured with the $\mathrm{C}_{18}$ substrate ranged between 0.18 and $0.48 \mathrm{U} \mathrm{mg}^{-1}$ protein within the digestive fluids and did not 
Fig. 2 Percentages of serine, cysteine and other proteases within the digestive fluid of $G$. natalis (a), D. celeste (b), B. latro $(\mathbf{c})$ and $C$. perlatus $(\mathbf{d})$. Data $[$ mean $\pm \operatorname{SEM}(n=5)]$ are expressed as a percentage of total protease activity. Serine and cysteine proteases were respectively inhibited by AEBSF and E64. Other proteases represent the proportion remaining after the serine and cysteine protease activities have been subtracted from the total protease activity. For each species, different letters above the bars indicate significantly different means $(P<0.05$, Kruskal-Wallis ANOVA followed by Student-NewmanKeuls post hoc tests on ranks)
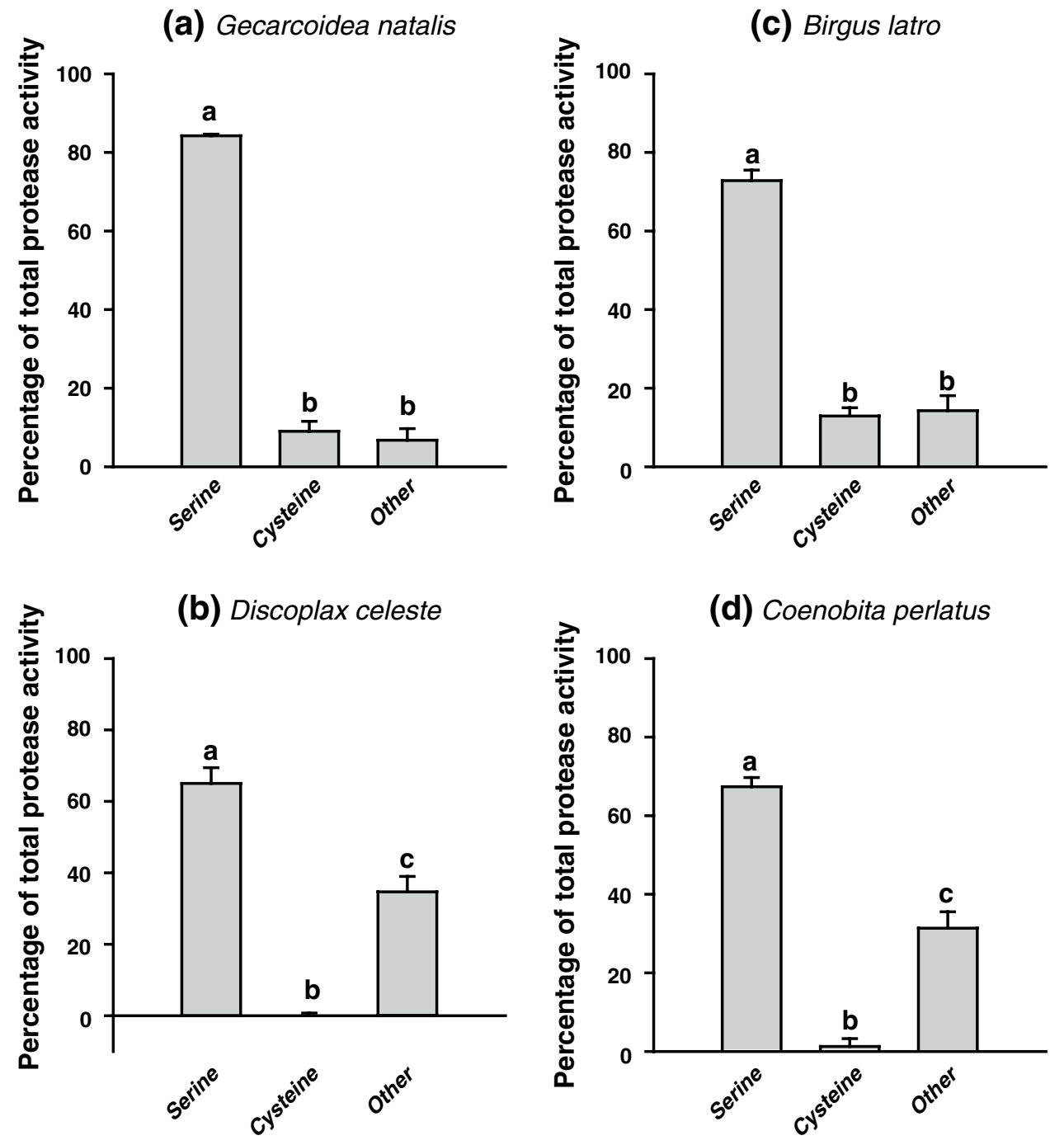

differ significantly among all species examined (Fig. 4a). The trends observed for the activities measured with the $\mathrm{C}_{4}$ substrate were different from that measured with the $\mathrm{C}_{18}$ substrate. The activities within the digestive fluid from $D$. celeste and C. perlatus were 0.28 and $0.30 \mathrm{U} \mathrm{mg}^{-1}$ protein, and thus significantly higher than those for $G$. natalis and B. latro, which amounted to 0.079 and $0.091 \mathrm{U} \mathrm{mg}^{-1}$ protein, respectively (Fig. 4b). These differences between the activities measured with the two substrates may have been due to the lipase enzymes being less efficient at hydrolysing the shorter substrate in a more aqueous environment. Alternatively the shorter substrate may possibly be hydrolysed by other esterase enzymes besides true lipases.

\section{Amylase}

Amylase hydrolyses $\alpha-1,4$-glycosidic bonds within storage polysaccharides such as starch and glycogen. The amylase activities within the digestive fluid of $G$. natalis, $D$. celeste, B. latro and C. perlatus ranged between 0.19 and $0.41 \mathrm{U} \mathrm{mg}^{-1}$ protein and did not differ statistically (Fig. 5).

\section{Chitinase}

Two enzymes are required to degrade chitin to its $N$-acetylglucosamine monomers. Chitinase cleaves internal $\beta-1,4-$ glycosidic bonds to produce short oligomers of 2-3 monosaccharides in length. $\mathrm{N}$-acetyl glucosamine is then hydrolysed from the non-reducing end by $N$-acetyl-D-glucosaminidase (EC 3.2.1.52) (Espie and Roff 1995; Terra and Ferreira 2005). Due to high variability, trends for $\mathrm{N}$-acetyl$\beta$-D-glucosaminidase activities were not as clear as for the other enzymes. The only clear difference was that the $N$-acetyl- $\beta$-D-glucosaminidase activity within the digestive fluid of $C$. perlatus was higher $\left(8.0 \times 10^{-5} \mathrm{U} \mathrm{mg}^{-1}\right.$ protein) than that from G. natalis $\left(1.3 \times 10^{-5} \mathrm{U} \mathrm{mg}^{-1}\right.$ protein) (Fig. 6). The $N$-acetyl- $\beta$-D-glucosaminidase activities within the digestive fluid from $D$. celeste, B. latro and $C$. 
Fig. 3 Chymotrypsin (a), trypsin (b), and alanine amino peptidase (c) specific activities within the digestive fluid of G. natalis, D. celeste, B. latro and $C$. perlatus. All specific activities were measured as the rate of release of $p$-nitrophenol from the hydrolysis of BAPNA for trypsin, SAPNA for chymotrypsin and L-alanine4-nitroanilide for alanine amino peptidase. Data are presented as mean $\pm \operatorname{SEM}(n=5)$. For each of the proteases, different letters above the bars indicate significantly different means (Trypsin: $P<0.05,1$-way ANOVA followed by Student-NewmanKeuls post hoc tests. Chymotrypsin and alanine amino peptidase: $P<0.05$, Kruskal-Wallis one-way ANOVA followed by Student-Newman-Keuls post hoc tests on ranks.) (a) Chymotrypsin

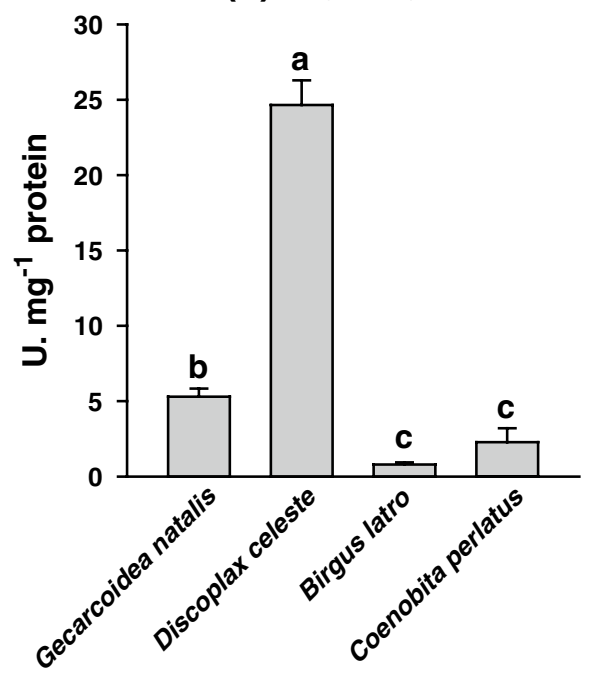

(c) Alanine amino peptidase

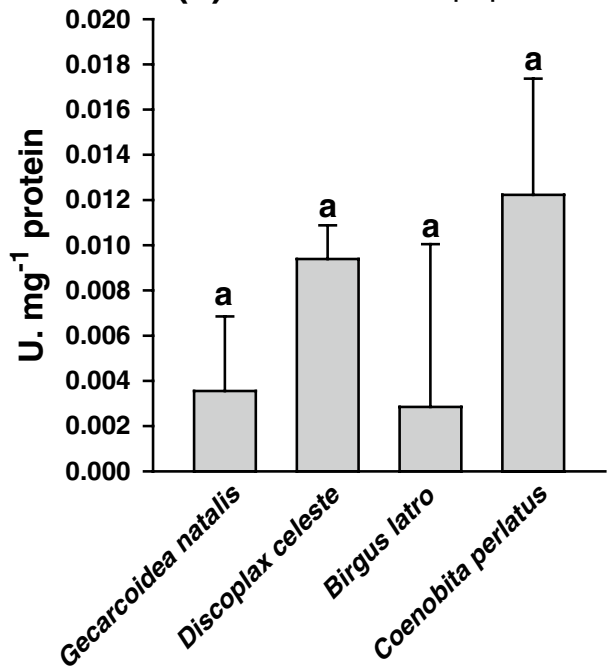

(b) Trypsin

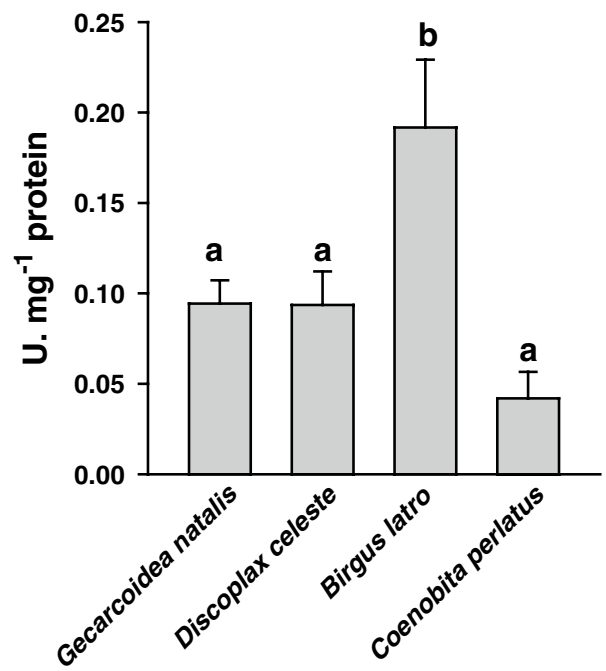

perlatus were similar (Fig. 6). In addition, the $N$-acetyl- $\beta$ D-glucosaminidase activities within the digestive fluid from G. natalis were not significantly different from those of $D$. celeste and B. latro (Fig. 6).

Cellulase and hemicellulase

Endo- $\beta$-1,4-glucanase is a cellulase which hydrolyses $\beta$-1,4-glycosidic bonds within cellulolytic substrates such as carboxy methyl cellulose. Endo- $\beta-1,4$-glucanase activities within the digestive fluids of $D$. celeste and C. perlatus were similar and higher than those of $G$. natalis and $B$. latro (Fig. 7). The endo- $\beta$-1,4-glucanase activities of these latter two species were similar (Fig. 7).

Lichenase hydrolyses $\beta$-1,4-glycosidic bonds within mixed-linkage polysaccharides such as lichenin and those found within the cell walls of protozoans, fungi and algae.
Lichenase activity within the digestive fluid from $C$. perlatus was higher $\left(0.85 \mathrm{U} \mathrm{mg}^{-1}\right.$ protein) than that from $D$. celeste, G. natalis and B. latro $\left(0.32-0.44 \mathrm{U} \mathrm{mg}^{-1}\right.$ protein) (Fig. 8). The lichenase activities within the digestive fluid from these last three species were similar (Fig. 8).

$\beta$-glucohydrolase, measured as $\beta$-1,4-glucosidase activity, is an enzyme that complements endo- $\beta-1,4-$ glucanase. It is thought to hydrolyse glucose off short polymers produced by endo- $\beta$-1,4-glucanase (Allardyce et al. 2010). $\beta$-1,4-glucosidase activities within the digestive fluid of $D$. celeste were approximately 20 times higher (0.11 $\mathrm{U} \mathrm{mg}^{-1}$ protein) than that for G. natalis, B. latro and $C$. perlatus, which were similar ranging between 0.002 and $0.007 \mathrm{U} \mathrm{mg}^{-1}$ protein (Fig. 9).

Laminarinase hydrolyses $\beta$-1,3-glycosidic bonds within laminarin; a glucose polymer joined by mainly $\beta-1,3-$ glycosidic bonds. The laminarinase activities ranged 
(a) 4-Methylumbelliferyl oleate

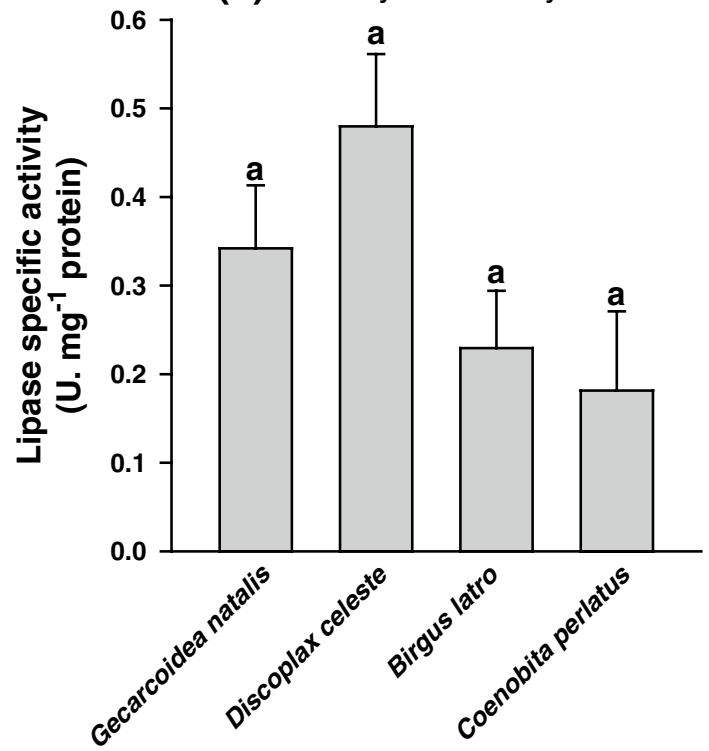

(b) 4-Methylumbelliferyl butyrate

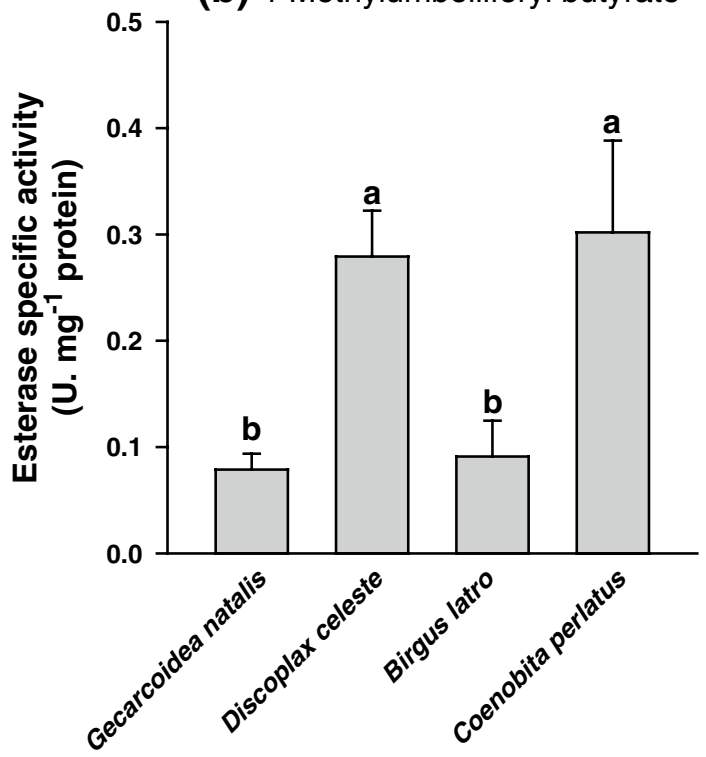

Fig. 4 Lipase-specific activities $\left(\mathrm{U} \mathrm{mg}^{-1}\right.$ protein) within the digestive fluid of $G$. natalis, $D$. celeste, B. latro and $C$. perlatus. Lipase activities were measured as the rate of release of the fluorescent molecule, 4- $\beta$-methylumbelliferone (MUF) from the hydrolysis of either MUF oleate (long $\mathrm{C}_{18}$ substrate) (a) or MUF butyrate (short $\mathrm{C}_{4}$ substrate) (b). Data are expressed as mean \pm SEM $(n=3-4)$. For enzyme assays within either MUF oleate or MUF butyrate, similar letters above the bars indicate similar means (lipase: $P>0.05$, oneway ANOVA. Esterase: $P<0.05$, one-way ANOVA followed by Student-Newman-Keuls post hoc tests)

between 1.18 and $1.63 \mathrm{U} \mathrm{mg}^{-1}$ protein. The activity was significantly higher within the digestive fluid of $C$. perlatus than in the digestive fluids from G. natalis, D. celeste and B. latro (Fig. 10).
Amylase

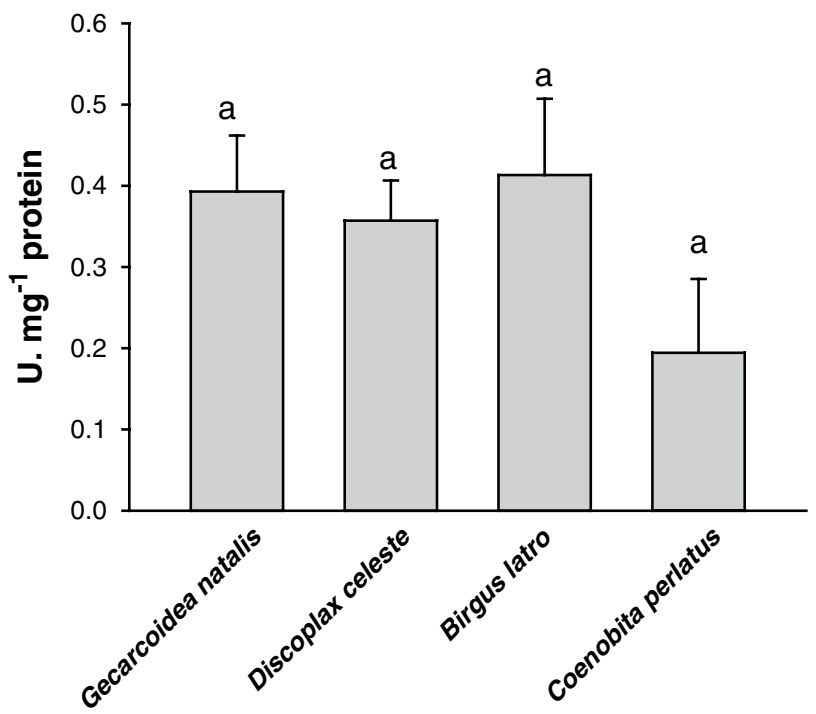

Fig. 5 Amylase-specific activities ( $\mathrm{U} \mathrm{mg}^{-1}$ protein) within the digestive fluid of $G$. natalis, D. celeste, B. latro and C. perlatus. Amylase activities were measured as the rate of production of reducing sugars from the hydrolysis of starch. Common letters above the bars indicate similar means $(P>0.05$, one-way ANOVA). Data are expressed as mean $\pm \operatorname{SEM}(n=5)$

\section{N-acetyl- $\beta$-D-glucosaminidase}

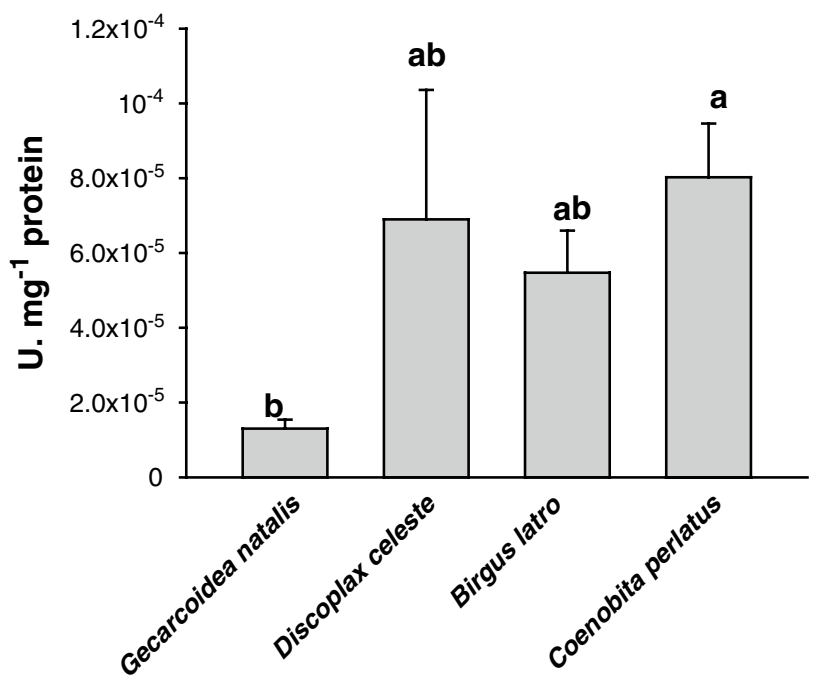

Fig. $6 N$-Acetyl- $\beta$-D-glucosaminidase-specific activities $\left(\mathrm{U} \mathrm{mg}^{-1}\right.$ protein) within the digestive fluid of $G$. natalis, D. celeste, B. latro and $C$. perlatus. $N$-Acetyl- $\beta$-D-glucosaminidase activities were measured as the rate of production of 4-methylumbelliferone from the hydrolysis of 4-methylumbelliferyl $N$-acetyl- $\beta$-D-glucosaminide. Different letters above the means indicate statistically different means $(P<0.05$, Kruskal-Wallis ANOVA followed by Dunn's post hoc tests on ranks). Data are expressed as mean $\pm \operatorname{SEM}(n=4)$ 


\section{Endo- $\beta-1,4-g l u c a n a s e$}

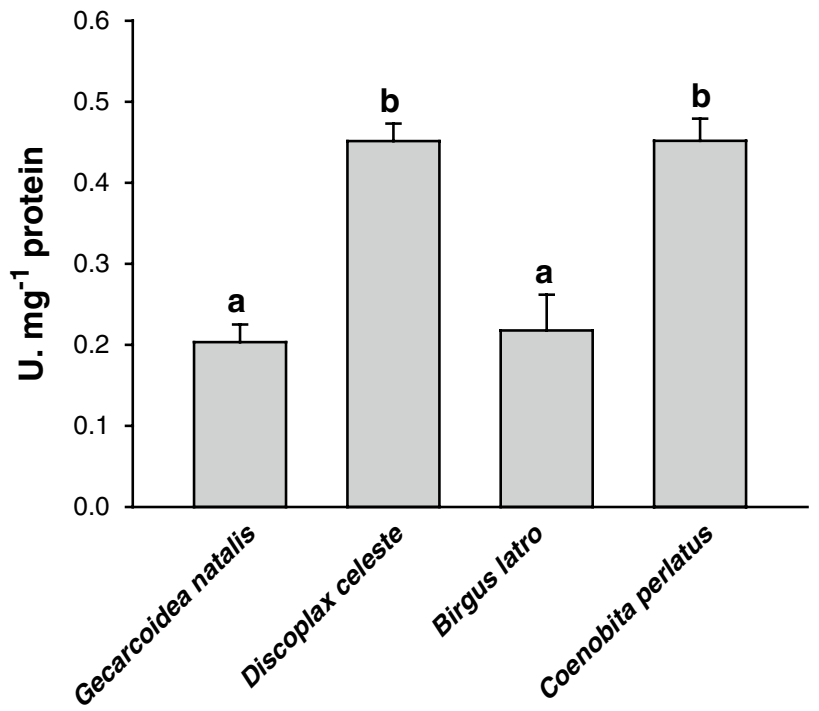

Fig. 7 Endo- $\beta$-1,4-glucanase-specific activities $\left(\mathrm{U} \mathrm{mg}^{-1}\right.$ protein) within the digestive fluid of $G$. natalis, D. celeste, B. latro and C. perlatus. Endo- $\beta$-1,4-glucanase activities were measured as the rate of production of reducing sugars from the hydrolysis of carboxy methyl cellulose. Different letters above the means indicate that they differed significantly $(P<0.05$, Kruskal-Wallis one-way ANOVA followed by Student-Newman-Keuls post hoc tests on ranks). Values are mean $\pm \operatorname{SEM}(n=5)$

\section{Lichenase}

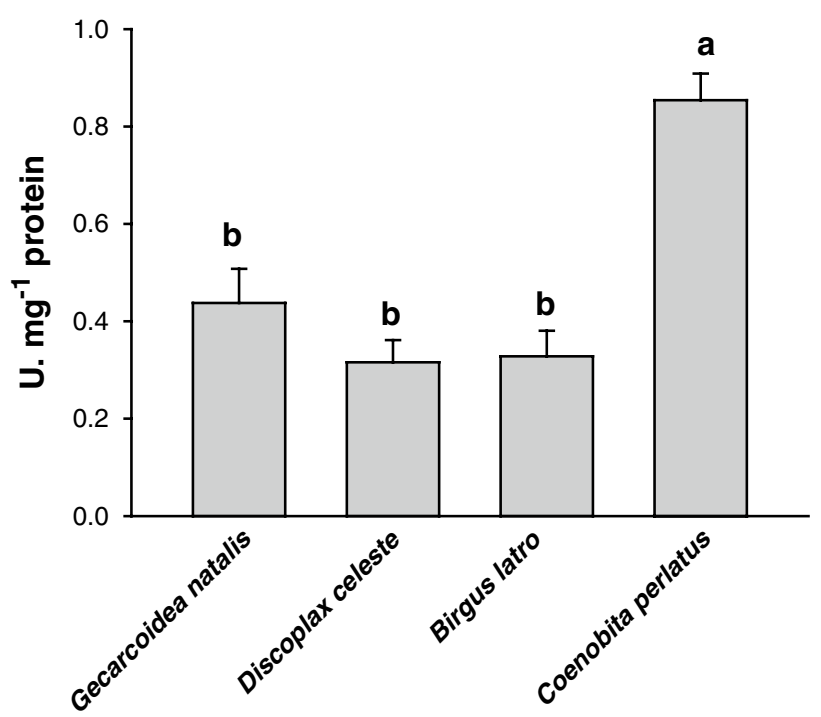

Fig. 8 Lichenase-specific activities $\left(\mathrm{U} \mathrm{mg}{ }^{-1}\right.$ protein) within the digestive fluid of G. natalis, D. celeste, B. latro and C. perlatus. Lichenase activities were measured as the production of reducing sugars from the hydrolysis of lichenan. Different letters above the means indicate that they were statistically different $(P<0.05$, oneway ANOVA followed by Student-Newman-Keuls post hoc tests). Values are mean $\pm \operatorname{SEM}(n=3-5)$

\section{$\beta$-glucohydrolase}

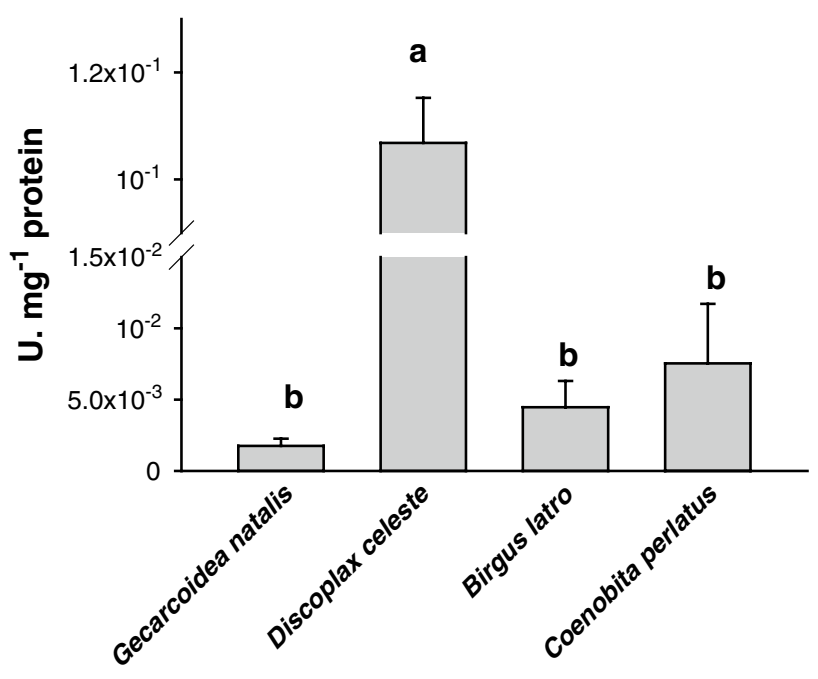

Fig. $9 \beta$-Glucohydrolase-specific activities $\left(\mathrm{U} \mathrm{mg}^{-1}\right.$ protein) within the digestive fluid of $G$. natalis, D. celeste, B. latro and C. perlatus. $\beta$-glucohydrolase activities were measured as $\beta$-1,4-glucosidase activity; that is, the production of glucose from the hydrolysis of cellobiose. Different letters above the means indicate that they differed significantly $(P<0.05$, Kruskal-Wallis one-way ANOVA followed by Student-Newman-Keuls post hoc tests on ranks). Data are expressed as mean $\pm \operatorname{SEM}(n=5)$

\section{Laminarinase}

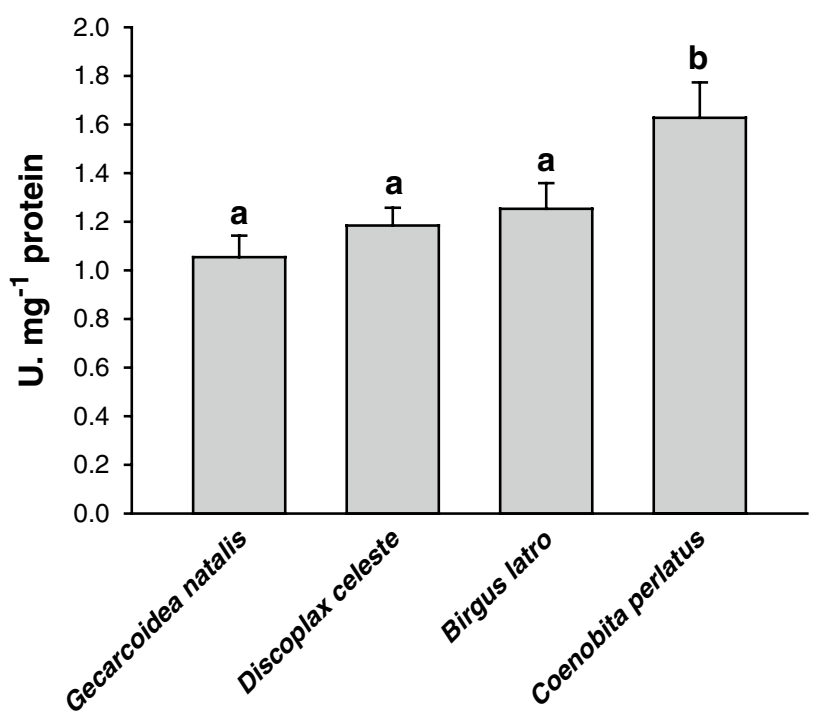

Fig. 10 Laminarinase-specific activities $\left(\mathrm{U} \mathrm{mg}^{-1}\right.$ protein) within the digestive fluid of $G$. natalis, D. celeste, B. latro and C. perlatus. Laminarinase activities were measured by the rate of production of reducing sugars from the hydrolysis of laminarin. Different letters above the bars indicate significantly different means $(P<0.05$, KruskalWallis one-way ANOVA followed by Student-Newman-Keuls post hoc tests on ranks). Data are expressed as mean $\pm \operatorname{SEM}(n=5)$ 


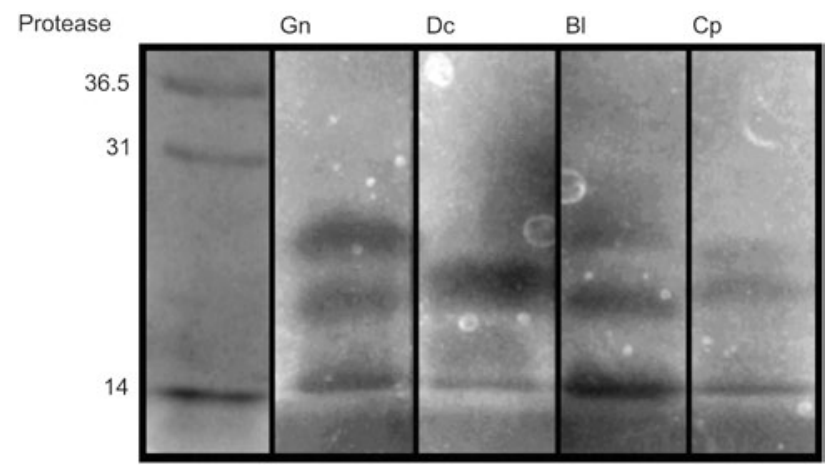

Fig. 11 Protease activity staining for the digestive fluid from $G$. natalis $(\mathrm{Gn})$, D. celeste $(\mathrm{Dc})$, B. latro $(\mathrm{Bl})$ and $C$. perlatus $(\mathrm{Cp})$. All digestive fluid samples were diluted by a factor of 250 times. Presence of protease activity was determined from the hydrolysis of $1 \%$ haemoglobin, which had been allowed to infuse into the polyacrylamide gel. Gels were fixed and stained with $0.05 \%$ Coomassie blue dissolved in a solution of $10 \%$ acetic acid, $40 \%$ methanol, $50 \%$ water to visualise the halos of protease activity and the molecular mass markers (Invitrogen Mark 12 unstained marker) of the sizes indicated

Size and number of digestive enzymes as revealed by zymography

\section{Protease activity staining}

Three protease bands of apparently 15, 19 and 21-22 kDa were observed for digestive fluid samples from $G$. natalis, B. latro and C. perlatus (Fig. 11; Table 4). The digestive fluid from $D$. celeste produced two protease activity bands, apparently 15 and $18 \mathrm{kDa}$ in size (Fig. 11; Table 4).

\section{Lipase/esterase activity staining}

Five lipase/esterase activity bands were observed from $G$. natalis. This included a strong fluorescent band at $129 \mathrm{kDa}$, and four smaller bands at 57, 51, 24.5 and $17 \mathrm{kDa}$ (Fig. 12; Table 4). The bands of 24,57 and $129 \mathrm{kDa}$ were unique to this species. The smallest band at $17 \mathrm{kDa}$ was next to the solvent front. For the other land crabs species examined, three lipase bands at $17,40-42$ and $48-50 \mathrm{kDa}$ were observed (Fig. 12; Table 4). All three bands were observed for B. latro and D. celeste (Table 4). Only one strong band at $33 \mathrm{kDa}$ was observed for $C$. perlatus (Table 4).The smaller activity bands at 17 and $25 \mathrm{kDa}$ may be due to serine proteases, such as trypsin and chymotrypsin, due to their similar sizes and they share the same catalytic triad as lipases and, thus, may possibly hydrolyse the butyrate substrate (Rivera-Perez et al. 2011).

\section{Alkaline phosphatase staining}

Alkaline phosphatases (EC 3.1.3.1) are unspecific phosphatases that remove the phosphate, through hydrolysis of the phosphoester bond, from various compounds before assimilation (Terra and Ferreira 2005).There are clear differences between the phosphatases present in the digestive fluids of the anomuran and brachyuran crabs. The $\mathrm{pH}$ optima
Table 4 Number of isoforms and apparent molecular mass $(\mathrm{kDa})$ of the various digestive enzymes present in the digestive fluid of the species listed

Presence of the enzymes was determined by activity staining. Number of replicates with each isoform is indicated in parentheses. For each enzyme, the highest number represents the total number of replicate digestive fluid samples examined

\begin{tabular}{|c|c|c|c|c|c|c|c|c|}
\hline \multirow[t]{2}{*}{ Enzyme } & \multicolumn{2}{|l|}{ G. natalis } & \multicolumn{2}{|l|}{ D. celeste } & \multicolumn{2}{|l|}{ B. latro } & \multicolumn{2}{|l|}{ C. perlatus } \\
\hline & Size (kDa) & $n$ & Size (kDa) & $n$ & Size (kDa) & $n$ & Size (kDa) & $n$ \\
\hline \multirow[t]{3}{*}{ Protease } & 22 & 4 & & & 22 & 2 & 21 & 3 \\
\hline & 18 & 4 & 18 & 3 & 18 & 3 & 19 & 3 \\
\hline & 15 & 4 & 15 & 3 & 15 & 3 & 15 & 3 \\
\hline \multirow[t]{6}{*}{ Esterase } & 129 & 3 & & & & & & \\
\hline & 57 & 3 & & & & & & \\
\hline & 51 & 3 & 48 & 3 & 50 & 3 & & \\
\hline & & & 40 & 3 & 41 & 3 & 33 & 3 \\
\hline & 24.5 & 3 & & & & & & \\
\hline & 17 & 3 & 17 & 3 & 17 & 3 & & \\
\hline \multirow[t]{2}{*}{ Phosphatase } & & & & & 75.5 & 4 & 73.5 & 2 \\
\hline & 50 & 1 & 48 & 4 & 55 & 5 & 52 & 3 \\
\hline Amylase & 58 & 2 & 59 & 2 & 58 & 2 & 60 & 2 \\
\hline \multirow[t]{4}{*}{$\beta$-Glucosidase } & 126 & 2 & 125 & 2 & & & 119 & 4 \\
\hline & 32 & 3 & 31 & 2 & 30 & 4 & & \\
\hline & 28 & 2 & 28 & 2 & & & 28 & 4 \\
\hline & 25 & 3 & & & & & & \\
\hline \multirow[t]{2}{*}{$N$-acetyl- $\beta$-D-glucosaminidase } & 97 & 3 & 92 & 3 & 94.5 & 5 & 94.5 & 3 \\
\hline & 76.5 & 3 & 76.5 & 3 & 76.5 & 1 & 77 & 1 \\
\hline
\end{tabular}




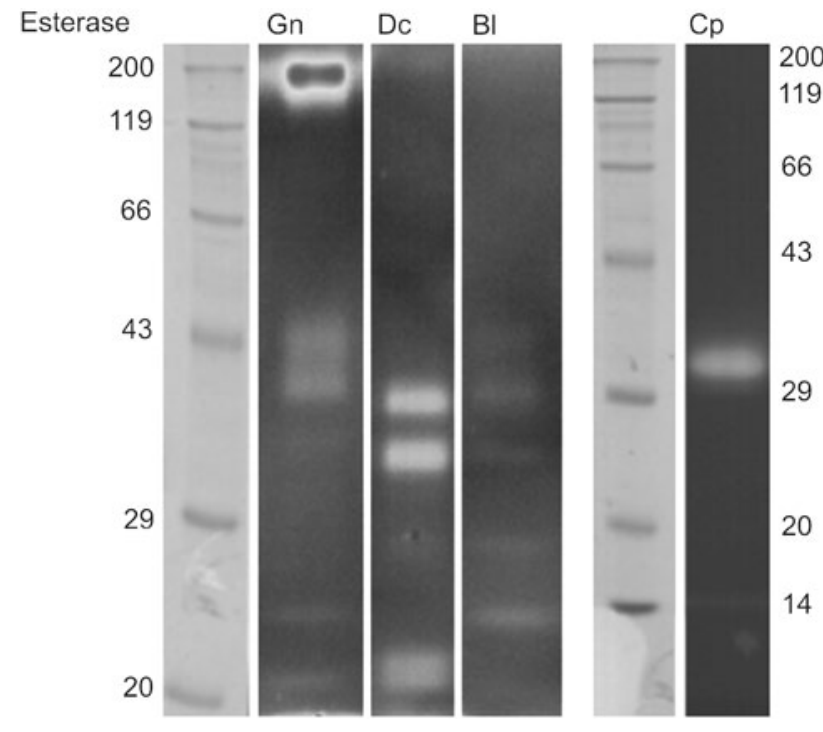

Fig. 12 Activity staining of polyacrylamide gels for esterase activity in the digestive fluid of the brachyuran land crabs, G. natalis $(\mathrm{Gn})$ and $D$. celeste $(\mathrm{Dc})$ and the anomuran land crabs, B. latro $(\mathrm{Bl})$ and $C$. perlatus $(\mathrm{Cp})$. Presence of esterase enzyme activities was determined using the substrate 4-methylumbelliferyl butyrate. The substrate is hydrolysed by the enzyme to release the fluorescent molecule, 4-methylumbelliferone. The digestive fluid samples from G. natalis, $D$. celeste and $B$. latro were diluted 1 in 1,000 times while those from C. perlatus were diluted by a factor of 2,500 times. Molecular mass markers (Carl Roth Roti-Mark standards), with sizes (kDa) indicated, were visualised by counterstaining gels with $0.05 \%$ Coomassie blue dissolved in a solution of $10 \%$ acetic acid, $40 \%$ methanol, $50 \%$ water

for the phosphatase activities of the anomuran crabs were between $\mathrm{pH} 9$ and 10 while that of the brachyurans was 8 , over the pH range tested (Fig. 13). Similarly, the zymograms revealed differences in the number and size of the phosphatases. The anomurans, $B$. latro and $C$. perlatus possessed two phosphatases, one of apparently 73.5-75.5 kDa and another of $52-55 \mathrm{kDa}$ (Fig. 14a; Table 4). In contrast, the brachyurans possessed only the smaller phosphatase which was apparently $48-50 \mathrm{kDa}$ in size (Fig. 14a; Table 4).

\section{Amylase activity staining}

One amylase activity band of apparently 58-60 kDa was observed for the digestive fluids from G. natalis, D. celeste, B. latro and C. perlatus (Fig. 14b).

Activity staining for enzymes that hydrolyse $\beta$-1,4-glycosidic bonds ( $\beta$-glucohydrolase and endo- $\beta$-1,4-glucanase)

The hydrolysis of the fluorescent substrate, 4-methylumbelliferyl- $\beta$-D-glucopyranoside by the digestive fluid samples produced activity bands at apparently
25, 28, 31-32 and 119-126 kDa (Fig. 14c; Table 4). This substrate is hydrolysed by enzymes that hydrolyse $\beta-1,4-$ glycosidic bonds; this includes $\beta$-glucohydrolyses and endo- $\beta$-1,4-glucanases/lichenases (Allardyce et al. 2010). The large fluorescent band at $119-126 \mathrm{kDa}$ is thought to be due to $\beta$-glucohydrolase, while the three smaller activity bands $(32,28$ and $25 \mathrm{kDa})$ are thought to be endo- $\beta-1,4-$ glucanase/lichenase isozymes that have been characterised previously (Linton and Shirley 2011; Allardyce and Linton 2008). These enzymes when run on SDS-PAGE gels without heating or reducing the sample with $\beta$-mercaptoethanol, the conditions used to create the zymograms, run further than samples which were heated and reduced. Thus under these conditions the $53-\mathrm{kDa}$ isozyme runs at $32 \mathrm{kDa}$, the $47-\mathrm{kDa}$ isozyme runs at $28 \mathrm{kDa}$ and the $43-\mathrm{kDa}$ isozyme runs at $25 \mathrm{kDa}$ (Linton and Shirley 2011). The digestive fluid from $G$. natalis produced three of the smaller endo- $\beta$ 1,4-glucanase activity bands, that from $D$. celeste produced two and the digestive fluid from $B$. latro and $C$. perlatus produced only one small endo- $\beta-1,4$-glucanase activity band; $30 \mathrm{kDa}$ for $B$. latro and $28 \mathrm{kDa}$ for $C$. perlatus. There was also variation between individuals of $G$. natalis; the digestive fluid from two out of three replicates produced three endo- $\beta-1,4$-glucanase activity bands, while that for the remaining replicates produced only two activity bands. The large activity band at $119-126 \mathrm{kDa}$ was feint for $G$. natalis and $D$. celeste and bright for $C$. perlatus. This band was not produced by the digestive fluid samples from $B$. latro.

\section{$N$-acetyl- $\beta$-D-glucosamine activity staining}

Two $N$-acetyl- $\beta$-D-glucosaminidase activity bands, one at apparently $77 \mathrm{kDa}$ and another at $92-97 \mathrm{kDa}$, were produced by the digestive fluid of the gecarcinids, G. natalis and D. celeste (Fig. 14d; Table 4). Both of these bands were present in all the replicates examined. Similarly, both bands were produced from the digestive fluid of the coenobitids B. latro and C. perlatus (Fig. 14d). For B. latro and C. perlatus the larger band was present in all the replicates examined, while the smaller band was only present in one out of five replicates for $B$. latro and one out of three replicates for $C$. perlatus (Table 4). Thus, individual polymorphism was observed for both coenobitid species.

\section{Discussion}

Major conclusions about the digestive enzyme activities

G. natalis, D. celeste, B. latro and C. perlatus possessed substantial activities of all the enzymes examined and this reflects their omnivorous nature. Thus they are capable of 
(a) Gecarcoidea natalis

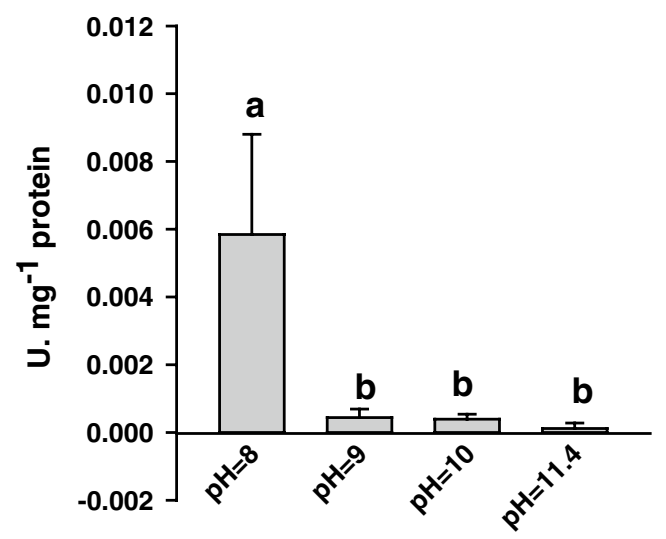

(b) Discoplax celeste

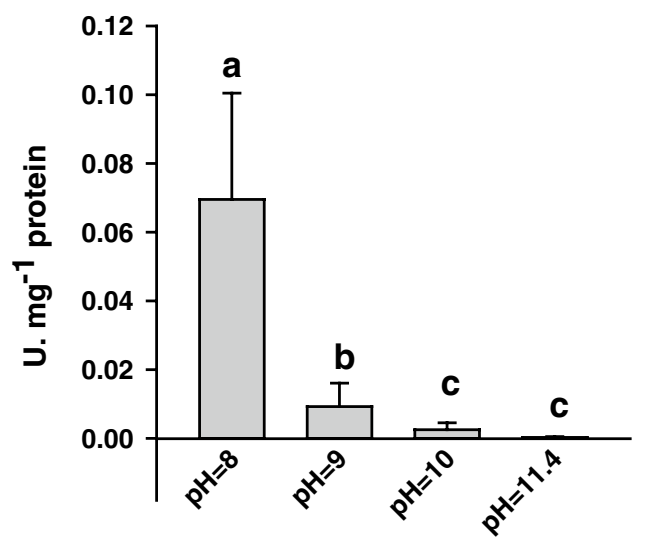

Fig. 13 Phosphatase-specific activities $\left(\mathrm{U} \mathrm{mg}^{-1}\right.$ protein) within the digestive fluid of $G$. natalis $(\mathbf{a}), D$. celeste $(\mathbf{b}), B$. latro $(\mathbf{c})$ and $C$. perlatus $(\mathbf{d})$. For each species, phosphatase activities were measured at $\mathrm{pH} \mathrm{8,9,10}$ and 11.4. Phosphatase activities were measured as the rate of release of $p$-nitrophenol from the hydrolysis of $p$-nitrophenol

hydrolysing and thus digesting protein, lipid and storage polysaccharides using respective protease, lipase and amylase enzymes. These activities are also consistent with the digestibilities of soluble cell contents (mainly protein, lipid and storage carbohydrate) from leaf litter consumed by $G$. natalis and D. celeste and high digestibilities for lipid, storage carbohydrate (starch/glycogen) and protein from artificial diets consumed by $B$. latro (Greenaway and Linton 1995; Greenaway and Raghaven 1998; Wilde et al. 2004). Similarly, the enzymes $N$-acetyl- $\beta$-D-glucosaminidase, endo- $\beta$-1,4-glucanase, $\beta$-glucohydrolase, lichenase and laminarinase for hydrolysing structural substrates such as chitin, cellulose and hemicellulose were present in all species examined. All cellulase and hemicellulase enzymes are likely to be produced endogenously given they are in G. natalis and a similar situation may also exist for other (c) Birgus latro

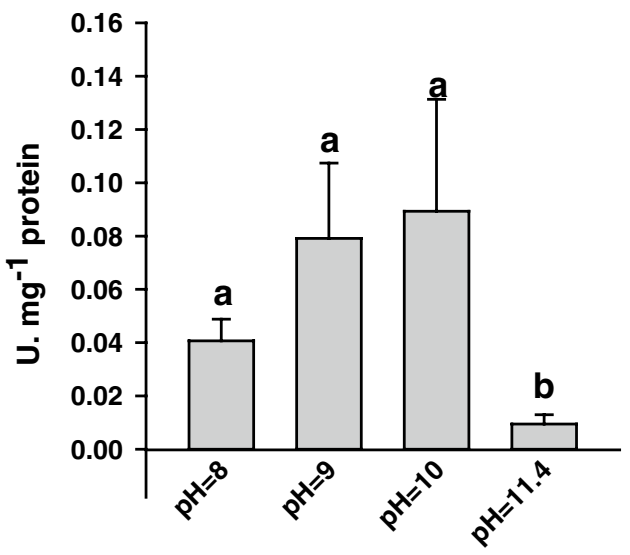

(d) Coenobita perlatus

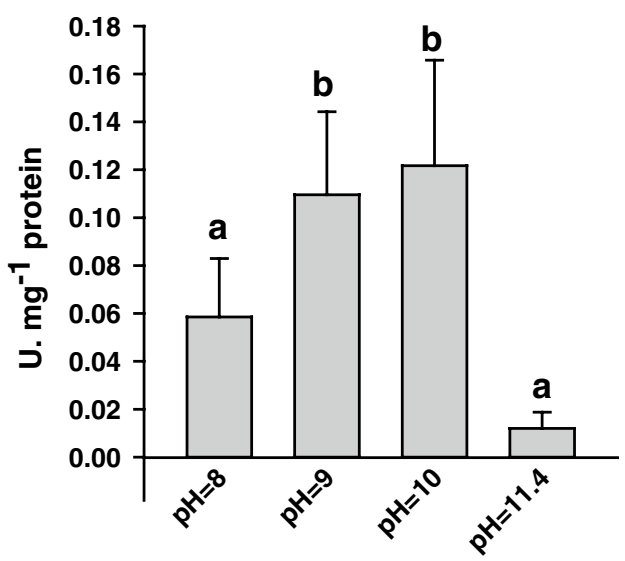

phosphate. Significantly different means, for each species, are indicated by different letters above the bars $(P<0.05$, Kruskal-Wallis one-way ANOVA followed by Student-Newman-Keuls post hoc tests on ranks for $G$. natalis, D. celeste and B. latro. One-way ANOVA followed Student-Newman-Keuls post hoc tests for C. perlatus)

species (Linton et al. 2006; Allardyce and Linton 2008; Allardyce et al. 2010). Again, these activities may explain the digestion of these structural substrates (Greenaway and Linton 1995; Greenaway and Raghaven 1998; Wilde et al. 2004). The digestive enzymes are also likely to be directly inherited from an aquatic ancestor given the presence and similar sizes of the isozymes (protease, lipase, amylase, $N$-acetyl- $\beta$-D-glucosaminidase, phosphatase, endo- $\beta-1,4$ glucosidase) between the two groups of land crabs and other aquatic decapods and arthropods (Tables 4,5 ).

During the colonisation of land, there was a little need for change in the majority of digestive enzymes given similar nutrients such as protein, lipid, storage carbohydrate and chitin that are present at similar concentrations in both terrestrial and aquatic environments. There may have been some evolutionary specialisation of enzymes for a 
(a) Phosphatase
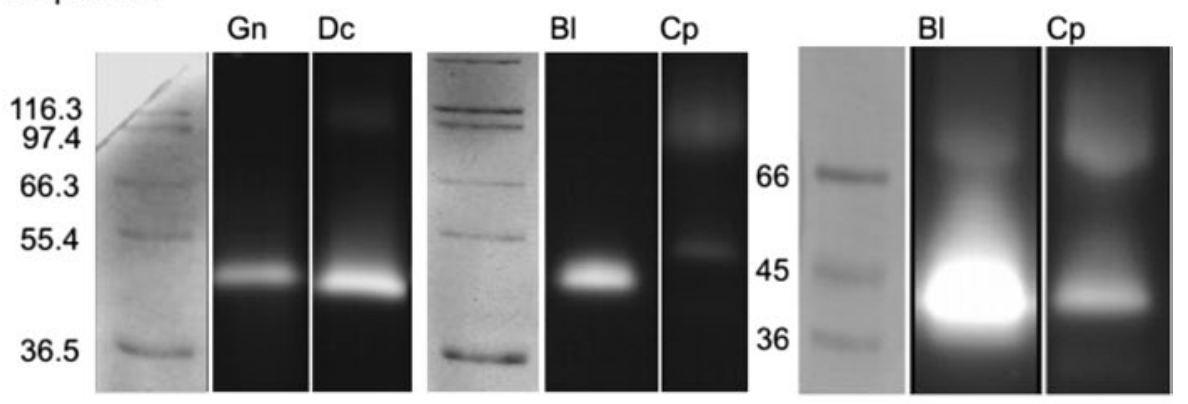

(b) Amylase
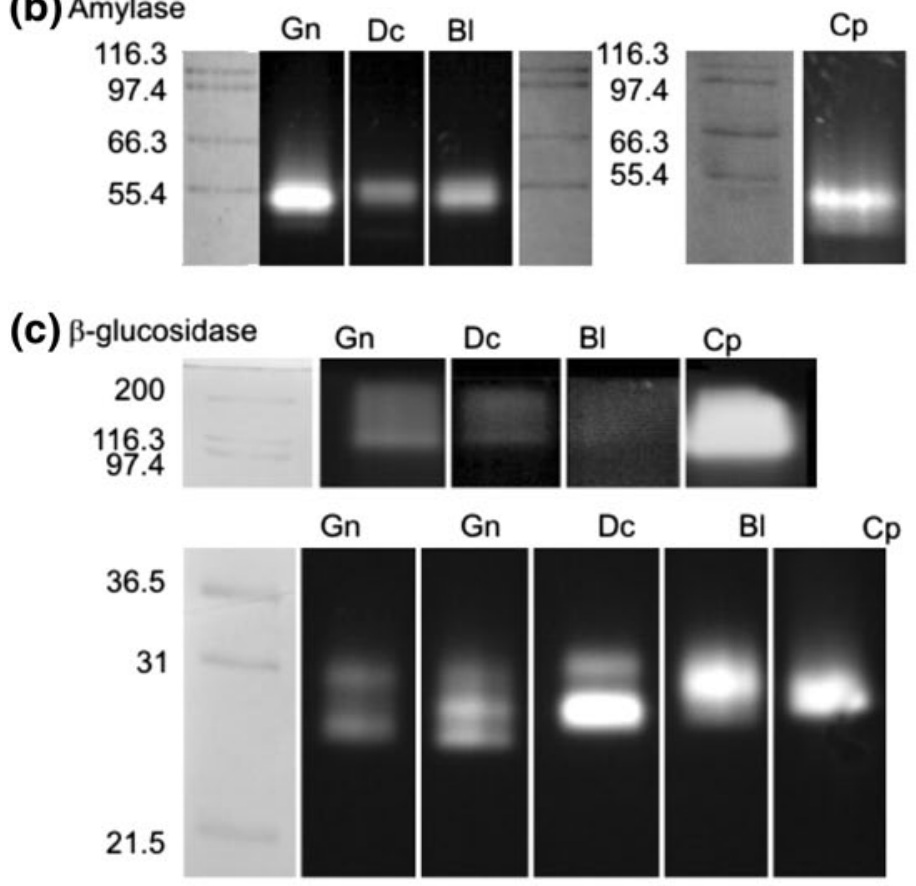

\section{(d) $\mathrm{N}$-acetyl- $\beta$ - $\mathrm{D}$-glucosaminidase}

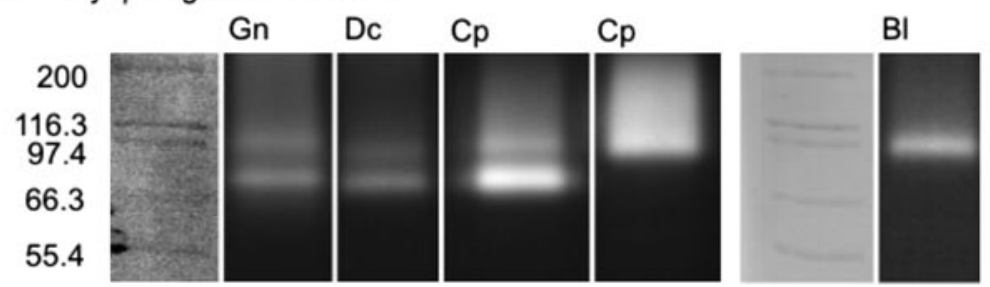

Fig. 14 Activity staining of polyacrylamide gels for enzymes with phosphatase (a), amylase (b), $\beta$-glucosidase (c) and $N$-acetyl$\beta$-D-glucosaminidase (d) activity, in the digestive fluid from the brachyuran land crabs, G. natalis $(\mathrm{Gn})$ and D. celeste $(\mathrm{Dc})$ and the anomuran land crabs, B. latro $(\mathrm{Bl})$ and $C$. perlatus $(\mathrm{Cp})$. Presence of amylase, $\beta$-glucosidase, $N$-acetyl- $\beta$-D-glucosaminidase and phosphatase enzyme activities was determined using the respective substrates 4-methylumbelliferyl- $\alpha$-D-glucopyranoside, 4-methylumbelliferyl- $\beta$-D-glucopyranoside, 4-methylumbelliferyl $N$-acetyl- $\beta$-D-glucosaminide and 4-methylumbelliferyl phosphate. These substrates are hydrolysed by the relevant enzyme to release the fluorescent molecule, 4-methylumbelliferone. Digestive fluid from $G$. natalis, D. celeste and C. perlatus were diluted by a factor of 10 times, while that from B. latro was diluted by a factor of 30 times for phosphatase activity staining (a). For amylase zymography (b), digestive fluid samples were diluted by a factor of 100 times for G. natalis, D. celeste and B. latro and 5 times for C. perlatus. For $\beta$-glucosidase activity (c), the digestive fluid samples were diluted by a factor of 5 times for large molecular mass isozymes and 100 times for low molecular mass isozymes. For $N$-acetyl- $\beta$-D-glucosaminidase activity staining (d), the digestive fluid samples were diluted by a factor of ten times. Molecular mass markers [Either Invitrogen Mark 12 unstained standard or SigmaMarker (M3913)], with sizes (kDa) indicated, were visualised by counterstaining gels with $0.05 \%$ Coomassie blue dissolved in a solution of $10 \%$ acetic acid, $40 \%$ methanol, $50 \%$ water 
Table 5 Apparent molecular mass (kDa) of digestive enzymes from other arthropods

\begin{tabular}{|c|c|c|c|}
\hline Enzyme & Species and taxonomic group & Size (kDa) & References \\
\hline \multirow[t]{3}{*}{ Chymotrypsin } & Crangon crangon (shrimp) & $35,38,43$ (native) & Teschke and Saborowski (2005) \\
\hline & Crangon allmani (shrimp) & $20,22,23$ (native) & Teschke and Saborowski (2005) \\
\hline & Panulirus interruptus (lobster) & 21,60 (native) & Celis-Guerrero et al. (2004) \\
\hline \multirow[t]{10}{*}{ Trypsin } & Crangon crangon (shrimp) & 20 (native) & Teschke and Saborowski (2005) \\
\hline & Crangon allmani (shrimp) & 20 (native) & Teschke and Saborowski (2005) \\
\hline & Thenus orientalis (decapod) & 35 (denatured) & Johnston et al. (1995) \\
\hline & Penaeus vannamei (prawn) & $21,22,23$ (native) & Sainz et al. (2004) \\
\hline & & $30.2,32.9$ (denatured) & \\
\hline & & $31-32$ (denatured) & \\
\hline & Panulirus interruptus (lobster) & 10,22 (native) & Celis-Guerrero et al. (2004) \\
\hline & Penaeus japonicus (prawn) & 25 (denatured) & Galgani et al. (1985) \\
\hline & $\begin{array}{l}\text { Farfantepenaeus paulensis } \\
\quad \text { (shrimp) }\end{array}$ & $14.6-21.7$ & Lemos et al. (1999) \\
\hline & Cancer pagurus & 26 (denatured) & $\begin{array}{l}\text { Hehemann et al. (2007), Saborowski } \\
\text { et al. (2004) }\end{array}$ \\
\hline \multirow[t]{4}{*}{ Lipase } & Penaeus vannamei (prawn) & 44.8 (denatured) & Rivera-Perez et al. (2011) \\
\hline & Carcinus mediterraneus (crab) & 65 (denatured) & Cherif et al. (2007) \\
\hline & $\begin{array}{l}\text { Cherax quadricarinatus } \\
\text { (crayfish) }\end{array}$ & $43,46,63,118$ (native) & López-López et al. (2003) \\
\hline & Scorpio maurus (scorpion) & 50 (denatured) & Zouari et al. (2005) \\
\hline \multirow[t]{6}{*}{ Amylase } & $\begin{array}{l}\text { Eupagurus bernhardus (hermit } \\
\text { crab) }\end{array}$ & 55 (denature) & Van Wormhoudt et al. (1995) \\
\hline & Procambarus clarkii (crayfish) & 55 (denatured) & Van Wormhoudt et al. (1995) \\
\hline & Carcinus maenas (crab) & 30 (denatured) & Van Wormhoudt et al. (1995) \\
\hline & Penaeus vannamei (prawn) & 30 (denatured) & Van Wormhoudt et al. (1995) \\
\hline & Palaemon elegans & $30.5,33,53,58,75$ (denatured) & Van Wormhoudt and Favrel (1988) \\
\hline & Insects generally & $48-60$ & Terra and Ferreira (2005) \\
\hline \multirow[t]{3}{*}{ Alkaline phosphatase } & Homarus gammarus (lobster) & 47 (native), 60 (denature) $\mathrm{pH} \max 8-9$ & $\begin{array}{l}\text { Saborowski (personal communica- } \\
\text { tion) }\end{array}$ \\
\hline & Pandalus borealis (shrimp) & $\begin{array}{l}53-60 \text { (cDNA, denatured) subunits of } \\
\text { dimeric protein. } \mathrm{pH} \text { max 10-10.5 }\end{array}$ & Nilsen et al. (2001) \\
\hline & Penaeus monodon (Prawn) & $\begin{array}{l}\text { 35, } 46 \text { subunits of polymeric enzyme. } \\
\text { pH max } 9\end{array}$ & Lee and Chuang (1991) \\
\hline \multirow[t]{3}{*}{$N$-Acetyl- $\beta$-D-glucosaminidase } & Penaeus vannamei (prawn) & $105(2 \times 45$ subunits $)$ (denatured) & Xie et al. (2004) \\
\hline & Scylla serrata (crab) & $132(2 \times 65.8$ subunits $)$ (denatured) & Zhang et al. (2006) \\
\hline & Penaeus japonicus (prawn) & 37 (denatured), 57 (mass spec) & Kono et al. (1990) \\
\hline \multirow[t]{5}{*}{ Endo- $\beta$-1,4-glucanase } & Cherax quadricarinatus & 30,40 (native) & Xue et al. (1999) \\
\hline & & 48,50 (mass spec) & (Crawford et al. 2004) \\
\hline & Cherax destructor & 53 (denatured) & (Allardyce and Linton 2008) \\
\hline & Gecarcoidea natalis & $43,47,53$ (denatured) & Allardyce et al. (2010), Linton and \\
\hline & & $25,28,32$ (native) & $\begin{array}{l}\text { Shirley (2011), Allardyce and } \\
\text { Linton (2008) }\end{array}$ \\
\hline $\begin{array}{l}\beta \text {-glucohydrolase }(\beta-1,4- \\
\text { glucosidase) }\end{array}$ & Gecarcoidea natalis & 130-169 (native) & Allardyce et al. (2010) \\
\hline
\end{tabular}

Native indicates that the samples were neither heated nor reduced prior to polyacrylamide electrophoresis. Denatured indicates that the samples were denatured and reduced prior to SDS polyacrylamide electrophoresis. Mass spec indicates that the mass of the enzyme was determined by its mass spectrum on a time of flight mass spectrometer. cDNA indicates the size of the enzyme predicted from the translated amino acid sequence 
terrestrial, mainly leaf litter diet, particularly in the gecarcinids, G. natalis and D. celeste since these species possess isozymes that were not observed in the coenobitids. In particular, the gecarcinid crabs possessed additional endo- $\beta$ 1,4-glucanase isozymes: $G$. natalis possessed two extra isoforms and $D$. celeste one. Perhaps the increase in isozymes elevated cellulase activity that enhanced the efficiency of cellulose digestion. Additional endo- $\beta-1,4$-glucanases may have arisen through gene duplication of the GHF9 gene. Two copies of a GHF9 gene are possessed by the isopod, Porcellio scaber (Kostanjšek et al. 2010) and individual termite species possess multiple copies of the GHF9 gene (Lo et al. 2011). Alternatively, the multiple endo- $\beta-1,4-$ glucanases may be due to the expression of different glycosyl hydrolase genes such as GHF1, GHF5, GHF9, GHF10 and GHF45 (Sakamoto et al. 2007, 2009; Sakamoto and Toyohara 2009a, b). The aquatic bivalve, Corbicula japon$i c a$, possesses and expresses such genes which account for its endo- $\beta-1,4$-glucanse, xylanase and $\beta$-1,4-glucosidase activities (Sakamoto et al. 2007, 2009; Sakamoto and Toyohara 2009a, b). Similarly, G. natalis possessed an additional lipase isozyme, a strong $129-\mathrm{kDa}$ band that was not present in the other species examined. This enzyme may be a true lipase or a general esterase that can hydrolyse soluble substrates. Gecarcinids consume substantial amounts of condensed and hydrolysable tannins with leaf litter and must be able to metabolise these compounds (Swain 1979; Hagerman and Butler 1991; Linton and Greenaway 2007). One possibility is the hydrolysis of hydrolysable tannins with an enzyme such as an esterase (Linton and Greenaway 2007). Differing in their $\mathrm{pH}$ optima and isozyme size, the phosphatases were also different between the gecarcinids and coenobitids. Again, there may have been evolution of the enzymes or the differences may be due to inheritance from different brachyuran and anomuran ancestors.

Activities of the digestive enzymes do not reflect the dietary preferences of the species examined

Except for $C$. perlatus, dietary preferences of the other species, G. natalis, D. celeste and B. latro were not reflected in the activities of the digestive enzymes. Other factors may be determining the observed feeding preferences. In particular, the restricted home ranges of G. natalis, D. celeste and $C$. perlatus may mean that the diet of these species is determined by the abundance of items found within it (Adamczewska and Morris 2001) (Table 1). For the gecarcinids, given this is mostly leaf litter, this is what they mostly eat. In contrast, the excellent olfactory and locomotor ability of B. latro allows it to travel large distances (up to $1 \mathrm{~km}$ ) to seek out its preferred dietary items (Table 1) (Greenaway 2001; Fletcher et al. 1990; Drew et al. 2010). In contrast, in other marine and intertidal crabs, the activities of their digestive enzymes commonly reflect their dietary preference. For example in other crab species, Plagusia chabrus and Thenus orientalis are carnivores with high activities of proteinase and amylase; Leptograpsus variegatus is an omnivore that consumes mainly green and brown algae and has high activities of amylase and laminarinase; Nectocarcinus integrifons is herbivorous, consuming sea grass, and possesses high cellulase activities; both Plagusia chabrus and Carcinus maenas are omnivores with similar levels of proteinase, amylase, laminarinase and cellulase (Johnston and Freeman 2005; Johnston et al. 1995). Similarly in talitrid amphipods, dietary preference is reflected in enzyme activity; Talorchestia marmorata consumes brown algae and possesses high laminarinase and lipase activities to digest the laminarin and lipid esters; an intertidal Talorchestia sp. consumes mainly diatoms and possesses high activities of $\alpha$ - and $\beta$-glucosidases for the digestion of the cell wall and starch; like the herbivorous land crabs, the litter feeder, Keratroides vulgaris possess relative low activities of all digestive enzymes (Johnston et al. 2005). Perhaps, the land crabs are like the other omnivorous crustaceans that possess similar activities of the digestive enzymes to deal with the variety of compounds within their opportunistic diet.

The activities of cellulase (endo- $\beta-1,4$-glucanase) and hemicellulase (lichenase and laminarinase) enzymes within the digestive fluid of $C$. perlatus were higher than those of other species, particularly compared to B. latro. This suggests that $C$. perlatus is capable of substantial digestion of cellulose and hemicellulose, and may thus have a preference for lower grade plant items that contain these compounds. Conversely, the lower cellulase (endo- $\beta-1,4-$ glucanase) and hemicellulase (laminarinase and lichenase) activities for B. latro compared to that for $C$. perlatus suggest that these compounds are not as important for energy as the highly digestible ones. However, the presence of the enzymes in $B$. latro is consistent with the digestion of small amounts of hemicellulose and cellulose by the crab when fed artificial plant-based diets (Wilde et al. 2004). B. latro would not derive substantial energy from cellulose digestion given its highly nutritious diet (Wilde et al. 2004). Thus, it is surprising that the digestive fluid possesses endo- $\beta$-1,4-glucanase activity. Indeed the apparent lack of $\beta$-glucohydrolyase in $B$. latro, as suggested by activity staining, suggests that this species is incapable of hydrolysing cellulose to glucose. The carnivorous mud crab, Scylla serrata also possesses endo- $\beta$-1,4-glucanase activities within its midgut gland (Pavasovic et al. 2004). Like $B$. latro, this species would not derive a significant amount of energy from cellulose digestion. Perhaps, the endo- $\beta-1,4-$ glucanase enzyme in these species contributes to the digestive efficiency. The activity of the endo- $\beta-1,4$-glucanase plus that of the gastric mill may help to degrade the fibrous 
pulp of fruits and other plant materials to release the preferred and highly digestible lipid, protein and carbohydrate (Wilde et al. 2004).

The activities for the enzymes that hydrolyse highly digestible substrates: total protease, amylase and lipase, within the digestive fluid of $B$. latro were not higher than those of other species. Thus, the preference of this species for highly digestible nutrients (protein, lipid and carbohydrate) is not reflected in the enzyme activities (Wilde et al. 2004). However, the activities of these enzymes are presumably high enough to achieve the high digestibility coefficients for nitrogen/protein, lipid and carbohydrate previously measured for this species (Wilde et al. 2004).

The gecarcinids were surprising in that the activities of their digestive enzymes, in particular the cellulase and hemicellulase enzymes, were similar to each other and to $B$. latro but were lower than that for $C$. perlatus. The enzyme activities for $G$. natalis were particularly surprising in that endo- $\beta-1,4$-glucanase activity was not higher than that for other species; particularly, D. celeste and total protease activities were higher than the total protease activities of other species. This is different to that described previously where endo- $\beta-1,4$-glucanase activities for $G$. natalis were higher than that for $D$. celeste, laminarinase activities similar, and lichenase activities higher for D. celeste (Linton and Greenaway 2004). As observed previously, $\beta$-glucohydrolase activity ( $\beta$-glucosidase activity) was higher in D. celeste than G. natalis (Linton and Greenaway 2004). However, the substantial activities of the cellulase and hemicellulase enzymes can explain the substantial cellulose and hemicellulose digestibilities observed for these species when fed on leaf litter diets (Greenaway and Linton 1995; Greenaway and Raghaven 1998).

The digestive fluid was sampled from individuals of $G$. natalis at the end of the dry season, just before the start of the reproductive migration. These animals were mostly confined to their burrows and may have been in "dry season mode" with a suppressed metabolism (different energetic metabolism to migrating wet season animals) (Morris et al. 2010). There may have been phenotypic plasticity in the expression of their digestive enzymes, in particular cellulase and hemicellulase enzymes may have been downregulated and the enzymes involved in the hydrolysis of highly nutritious substrates, lipase, protease and amylase upregulated. This may be required to gain energy and nitrogen for reproductive purposes. Alternatively, the high total protease activity may reflect the efficient hydrolysis and thus digestion of the low amount of protein associated with a mainly leaf litter diet (Linton and Greenaway 2007). Although phenotypic plasticity of digestive enzymes remains to be demonstrated in land crabs, it has been observed in other decapod crustaceans and insects (Locusta migratoria). Activities of $\alpha$-amylase in the midgut gland of mud crabs, Scylla serrata increase when the crabs are fed diets increasing in starch (Pavasovic et al. 2004). Similarly, activities of the digestive enzymes, $\alpha$-amylase, endo- $\beta-1,4$-glucanase and protease within the crayfish, $C$. quadricarinatus, are positively correlated to the protein and carbohydrate content of the diet (Pavasovic et al. 2007a, b). In contrast, the locust, Locusta migratoria downregulates $\alpha$-amylase and $\alpha$-chymotrypsin levels in response to excessive intake of carbohydrate or protein (Clissold et al. 2010). This downregulation of enzyme activity is thought to decrease the absorption of excess nutrients as the animal tries to achieve its most optimal intake of both carbohydrate and protein from a very nutrient deficient diet. A similar mechanism may occur in $G$. natalis at the end of the dry season as this species would have a restricted diet of mainly leaf litter and would, consequently, have a high intake of structural carbohydrates such as cellulose and hemicellulose.

Acknowledgments The authors are grateful to the Hermon Slade Foundation for funding this work.

\section{References}

Adamczewska AM, Morris S (2001) Ecology and behavior of Gecarcoidea natalis, the Christmas Island Red Crab, during the annual breeding migration. Biol Bull 200:305-320

Allardyce BJ, Linton SM (2008) Purification and characterisation of endo- $\beta$-1,4-glucanase and laminarinase enzymes from the gecarcinid land crab Gecarcoidea natalis and the aquatic crayfish Cherax destructor. J Exp Biol 211(14):2275-2287

Allardyce BJ, Linton SM, Saborowski R (2010) The last piece in the cellulase puzzle: the characterisation of $\{$ beta $\}$-glucosidase from the herbivorous gecarcinid land crab Gecarcoidea natalis. J Exp Biol 213(17):2950-2957. doi:10.1242/jeb.041582

Barnes DKA (1997) Ecology of tropical hermit crabs at Quirimba Island, Mozambique: a novel and locally important food source. Mar Ecol Prog Ser 161:299-302

Bradford MM (1976) A rapid and sensitive method for the quantitation of microgram quantities of protein utilizing the principle of protein-dye binding. Anal Biochem 72(1-2):248-254

Celis-Guerrero LE, García-Carreño F, del Toro MAN (2004) Characterization of proteases in the digestive system of spiny lobster (Panulirus interruptus). Mar Biotechnol 6:262-269

Cherif S, Fendri A, Miled N, Trabelsi H, Mejdoub H, Gargouri Y (2007) Crab digestive lipase acting at high temperature: purification and biochemical characterization. Biochimie 89(8):1012-1018

Clissold FJ, Tedder BJ, Conigrave AD, Simpson SJ (2010) The gastrointestinal tract as a nutrient-balancing organ. Proc Royal Soc B: Biol Sci 277(1688):1751-1759. doi:10.1098/r spb.2009.20452009.2045

Crawford AC, Kricker JA, Anderson AJ, Richardson NA, Mather PB (2004) Structure and function of a cellulase gene in redclaw crayfish Cherax quadricarinatus. Gene 340:267-274

Davie PJF (2002) Crustacea: Malacostraca: Eucarida (Part 2): Decapoda-Anomura, Brachyura. In: Wells A, Houston WWK (eds) Zoological catalogue of Australia, vol 19.3B. CSIRO Publishing, Melbourne, p xiv 641 
del Toro MAN, García-Carreño FL, Lopez MD, Celis G, Laura E, Saborowski R (2006) Aspartic proteinases in the digestive tract of marine decapod crustaceans. J Exp Zool 305A:645-654

Díaz-Tenorio LM, García-Carreño FL, del Toro MAN (2006) Characterization and comparison of digestive proteinases of the Cortez swimming crab, Callinectes bellicosus, and the arched swimming crab, Callinectes arcuatus. Invertebr Biol 125(2):125-135

Drew MM, Harzsch S, Stensmyr M, Erland S, Hansson BS (2010) A review of the biology and ecology of the Robber Crab, Birgus latro (Linnaeus, 1767) (Anomura: Coenobitidae). Zoologischer Anzeiger-J Comp Zool 249(1):45-67

Espie PJ, Roff JC (1995) Characterization of Chitobiase from Daphnia magna and its relation to chitin flux. Physiol Zool 68(5):727-748

Figueiredo MSRB, Kricker JA, Anderson AJ (2001) Digestive enzyme activities in the alimentary tract of redclaw crayfish, Cherax quadricarinatus (Decapoda: Parastacidae). J Crustac Biol 21(2):334-344

Fletcher WJ, Brown IW, Fielder DR (1990) Movement of coconut crabs, Birgus latro, in rainforest habitat in Vanuatu. Pac Sci 44(4):407-416

Galgani FG, Benyamin Y, Van Wormhoudt A (1985) Purification, properties and immunoassay of trypsin from the shrimp Penaeus japonicus. Comp Biochem Physiol Part B: Comp Biochem 81(2):447-452

García-Carreño FL, Dimes LE, Haard NF (1993) Substrate-gel electrophoresis for composition and molecular weight of proteinases or proteinaceous proteinase inhibitors. Anal Biochem 214(1):65-69

German DP, Nagle BC, Villeda JM, Ruiz AM, Thomson AW, Contreras Balderas S, Evans DH (2010) Evolution of herbivory in a carnivorous clade of minnows (Teleostei: Cyprinidae): effects on gut size and digestive physiology. Physiol Biochem Zool: PBZ 83(1):1-18. doi: $10.1086 / 648510$

Gimenez AVF, García-Carreño FL, del Toro MAN, Fenucci JL (2002) Digestive proteinases of Artemesia longinaris (Decapoda, Penaeidae) and relationship with molting. Comp Biochem Physiol B 132:593-598

Greenaway P (2001) Sodium and water balance in free-ranging robber crabs, Birgus latro (Anomura: Coenobitidae). J Crustac Biol 21(2):317-327

Greenaway P (2003) Terrestrial adaptations in the Anomura (Crustacea: Decapoda). Mem Mus Vic 60(1):13-26

Greenaway P, Linton SM (1995) Dietary assimilation and food retention time in the herbivorous terrestrial crab Gecarcoidea natalis. Physiol Zool 68(6):1006-1028

Greenaway P, Raghaven S (1998) Digestive strategies in two species of leaf-eating land crabs (Brachyura: Gecarcinidae) in a rain forest. Physiol Zool 71(1):36-44

Grubb P (1971) Ecology of terrestrial decapod crustaceans on Aldabra. Philos Trans R Soc Lond 260:411-416

Hagerman AE, Butler LG (1991) Tannins and lignins. In: Rosenthal GA, Berenbaum MR (eds) Herbivores their interactions with secondary plant metabolites, vol 1, 2nd edn. Academic Press, San Diego, pp 355-386

Hartnoll RG (1988) Evolution, systematics, and geographical distribution. In: Burggren WW, McMahon BR (eds) Biology of the land crabs. Cambridge University Press, Cambridge, pp 7-53

Hehemann J-H, Redecke L, Perbandt M, Saborowski R, Betzel C (2007) Crystallization and preliminary X-ray diffraction studies of trypsin-like proteases from the gastric fluid of the marine crab Cancer pagurus. Acta Crystallogr Sect F 63(3):242-245. doi:10.1107/s1744309107008524

Hicks J, Rumpff H, Yorkston H (1990) Christmas crabs, 2nd edn. Christmas Island Natural History Association, Christmas Island
Johnston D, Freeman J (2005) Dietary preference and digestive enzymes activities as indicators of trophic resource utilization by six species of crab. Biol Bull 208:36-46

Johnston DJ, Yellowlees D (1998) Relationship between dietary preferences and digestive enzyme complement of the slipper lobster Thenus orientalis (Decapoda: Scyllaridae). J Crustac Biol 18(4):656-665

Johnston D, Hermans JM, Yellowlees D (1995) Isolation and characterization of a trypsin from the slipper lobster, Thenus orientalis (Lund). Arch Biochem Biophys 324(1):35-40

Johnston D, Ritar AJ, Thomas CW (2004) Digestive enzyme profiles reveal digestive capacity and potential energy sources in fed and starved spiny lobster (Jasus edwardsii) phyllosoma larvae. Comp Biochem Physiol B 138:137-144

Johnston M, Johnston D, Richardson A (2005) Digestive capabilities reflect the major food sources in three species of talitrid amphipods. Comp Biochem Physiol-B Biochem Mol Biol 140(2):251-257

Jue DK, Lipke PN (1985) Determination of reducing sugars in the nanomole range with tetrazolium blue. J Biochem Biophys Methods 11:109-115

Karasov WH, del Rio CM, Caviedes-Vidal E (2011) Ecological physiology of diet and digestive systems. In: Julius D, Clapham DE (eds) Annual review of physiology, vol 73. Annual review of physiology. Annual reviews, Palo Alto, pp 69-93. doi:10.1146/annurev-physiol-012110-142152

Knotz S, Boersma M, Saborowski R (2006) Microassays for a set of enzymes in individual small marine copepods. Comp Biochem Physiol-Mol Integr Physiol 145(3):406-411

Kono M, Matusi T, Shimizu C, Koga D (1990) Purifications and some properties of chitinase from the liver of a prawn. Penaeus japonicus. Agricultural Biological Chemistry 54(8):2145-2147

Kostanjšek R, Milatovič M, Štrus J (2010) Endogenous origin of endo- $\beta$-1,4-glucanase in common woodlouse Porcellio scaber (Crustacea, Isopoda). J Comp Physiol (B) 180(8):1143-1153. doi:10.1007/s00360-010-0485-7

Laemmli UK (1970) Cleavage of structural proteins during the assembly of the head of bacteriophage T4. Nature 227(5259):680-685

Lee A-C, Chuang N-N (1991) Characterization of different molecular forms of alkaline phosphatase in the hepatopancreas from the shrimp Penaeus monodon (Crustacea: Decapoda). Comp Biochem Physiol Part B: Comp Biochem 99(4):845-850

Lemos D, Hernández-Cortés MP, Navarrete A, García-Carreño FL, Phan VN (1999) Ontogenetic variation in digestive proteinase activity of larvae and postlarvae of the pink shrimp Farfantepenaeus paulensis (Crustacea: Decapoda: Penaeidae). Mar Biol 135(4):653-662. doi:10.1007/s002270050666

Linnaeus C (1767) Systema naturae per regna tria naturae, secundum classes, ordinies, genera, species cum character-bus, differentiis, synonymis, locis, 12 edn. Stockholm

Linton SM, Greenaway P (2004) Presence and properties of cellulase and hemicellulase enzymes of the gecarcinid land crabs Gecarcoidea natalis and Discoplax hirtipes. J Exp Biol 207:4095-4104

Linton SM, Greenaway P (2007) A review of feeding and nutrition of herbivorous land crabs: adaptations to low quality plant diets. J Comp Physiol B 177:269-286

Linton SM, Shirley AJ (2011) Isozymes from the herbivorous gecarcinid land crab, Gecarcoidea natalis that possess both lichenase and endo- $\beta-1,4$-glucanase activity. Comp Biochem Physiol-B Biochem Mol Biol 160(1):44-53

Linton SM, Greenaway P, Towle DW (2006) Endogenous production of endo- $\beta$-1,4-glucanase by decapod crustaceans. J Comp Physiol B 176:339-348

Lo N, Tokuda G, Watanabe H (2011) Evolution and function of endogenous termite cellulases. Biology of termites: A modern synthesis. Springer, Heidelberg 
López-López S, Nolasco H, Vega-Villasante F (2003) Characterization of digestive gland esterase-lipase activity of juvenile redclaw crayfish Cherax quadricarinatus. Comp Biochem Physiol B: Biochem Mol Biol 135(2):337-347

Milne Edwards H (1853) Histoire Naturelle des Crustaces. Librairie Encyclopedique de Roret (Paris) 2, p 532

Morris S, Postel U, Mrinalini P, Turner LM, Palmer J, Webster SG (2010) The adaptive significance of crustacean hyperglycaemic hormone $(\mathrm{CHH})$ in daily and seasonal migratory activities of the Christmas Island red crab Gecarcoidea natalis. J Exp Biol 213(17):3062-3073. doi:10.1242/jeb.045153

Ng PKL, Davie PJF (2012) The blue crab of Christmas Island, Discoplax celeste, new species (Crustacea: Decapoda: Brachyura: Gecarcinidae). Raffles Bull Zool 60(1):89-100

Nilsen IW, Øverbø K, Olsen RL (2001) Thermolabile alkaline phosphatase from Northern shrimp (Pandalus borealis): protein and cDNA sequence analyses. Comp Biochem Physiol B: Biochem Mol Biol 129(4):853-861

Park J, Cho SY, Choi SJ (2008) Purification and characterization of hepatic lipase from Todarodes pacificus. J Biochem Mol Biol 41(3):254-258

Pavasovic M, Richardson NA, Anderson AJ, Mann D, Mather PB (2004) Effect of $\mathrm{pH}$, temperature and diet on digestive enzyme profiles in the mud crab, Scylla serrata. Aquaculture 242(1-4):641-654

Pavasovic A, Anderson AJ, Mather PB, Richardson NA (2007a) Effect of a variety of animal, plant and single cell-based feed ingredients on diet digestibility and digestive enzyme activity in redclaw crayfish, Cherax quadricarinatus (Von Martens 1868). Aquaculture 272(1-4):564-572. doi:10.1016/j.aquaculture.2007.08.027

Pavasovic A, Anderson AJ, Mather PB, Richardson NA (2007b) Influence of dietary protein on digestive enzyme activity, growth and tail muscle composition in redclaw crayfish, Cherax quadricarinatus (von Martens). Aquac Res 38(6):644-652. doi:10.1111/j.1365-2109.2007.01708.x

Pocock RI (1888) On the Arachnida, Myriopoda, and land-Crustacea of Christmas Island. Proc Zool Soc Lond 56(1):556-564

Prim N, Sánchez M, Ruiz C, Javier Pastor FI, Díaz P (2003) Use of methylumbeliferyl-derivative substrates for lipase activity characterization. J Mol Catal B Enzym 22(5-6):339-346

Rivera-Pérez C, del Toro MAN, García-Carreño F (2011) Purification and characterization of an intracellular lipase from pleopods of whiteleg shrimp (Litopenaeus vannamei). Comp Biochem Physiol—B Biochem Mol Biol 158(1):99-105

Saborowski R, Sahlinga G, Navarette del Toro MA, Waltera I, GarcíaCarreñob FL (2004) Stability and effects of organic solvents on endopeptidases from the gastric fluid of the marine crab Cancer pagurus. J Mol Catal B: Enzym 30(3-4):109-118

Sainz JC, García-Carreño FL, Hernández-Cortés P (2004) Penaeus vannamei isotrypsins: purification and characterization. Comp Biochem Physiol B 138:155-162

Sakamoto K, Toyohara H (2009a) Molecular cloning of glycoside hydrolase family 45 cellulase genes from brackish water clam Corbicula japonica. Comp Biochem Physiol B: Biochem Mol Biol 152(4):390-396
Sakamoto K, Toyohara H (2009b) Putative endogenous xylanase from brackish-water clam Corbicula japonica. Comp Biochem Physiol B: Biochem Mol Biol 154(1):85-92

Sakamoto K, Touhata K, Yamashita M, Kasai A, Toyohara H (2007) Cellulose digestion by common Japanese freshwater clam Corbicula japonica. Fish Sci 73:675-683

Sakamoto K, Uji S, Kurokawa T, Toyohara H (2009) Molecular cloning of endogenous [beta]-glucosidase from common Japanese brackish water clam Corbicula japonica. Gene 435(1-2):72-79

Schondube JE, Herrera-M LG, Martínez del Rio C (2001) Diet and the evolution of digestion and renal function in phyllostomid bats. Zoology 104(1):59-73. doi:10.1078/0944-2006-00007

Stensmyr MC, Erland S, Hallberg E, Wallen R, Greenaway P, Hansson BS (2005) Insect-like olfactory adaptations in the terrestrial giant robber crab. Curr Biol 15:116-121

Swain T (1979) Tannins and lignins. In: Rosenthal GA, Janzen DH (eds) Herbivores, their interaction with secondary plant metabolites. Academic press, New York, pp 657-682

Terra WR, Ferreira C (2005) Biochemistry of digestion. In: Sarjeet $\mathrm{S}$ (ed) Comprehensive molecular insect science. Elsvier, Amsterdam, New York, pp 171-224

Teschke M, Saborowski R (2005) Cysteine proteinases substitute for serine proteinases in the midgut glands of Crangon crangon and Crangon allmani (Decapod: Caridea). J Exp Mar Biol Ecol 316:213-229

Van Wormhoudt A, Favrel P (1988) Electrophoretic characterization of Palaemon elegans (crustacea, decapoda) alpha-amylase system: study of amylase polymorphism during the intermolt cycle. Comp Biochem Physiol Part B: Comp Biochem 89(2):201-207

Van Wormhoudt A, Bourreau G, Le Moullac G (1995) Amylase polymorphism in crustacea decapoda: electrophoretic and immunological studies. Biochem Syst Ecol 23(2):139-149

Vonk HJ, Western JRH (1984) Comparative biochemistry and physiology of enzymatic digestion. Academic Press, New York

Wilde JE, Linton SM, Greenaway P (2004) Dietary assimilation and the digestive strategy of the omnivorous anomuran land crab Birgus latro (Coenobitidae). J Comp Physiol B 174:299-308

Xie X-L, Chen Q-X, Lin J-C (2004) Purification and some properties of $\beta-N$-acetyl-D-glucosaminidase from prawn (Penaeus vannamei). Mar Biol 146:143-148

Xue XM, Aderson AJ, Richardson NA, Anderson AJ, Xue GP, Mather PB (1999) Characterisation of cellulase activity in the digestive system of the redclaw crayfish (Cherax quadricarinatus). Aquaculture 180:373-386

Zhang J-P, Chen Q-X, Wang Q, Xie J-J (2006) Purification and some properties of $\beta$ - $N$-acetyl-D-glucosaminidase from viscera of green crab (Scylla serrata). Biochemistry (Moscow) 71(Suppl. 1):S55-S59

Zouari N, Miled N, Cherif S, Mejdoub H, Gargouri Y (2005) Purification and characterization of a novel lipase from the digestive glands of a primitive animal: the scorpion. Biochimica et Biophy Acta-Gen Subj 1726(1):67-74 